Włodzimierz Batóg

Uniwersytet Jana Kochanowskiego

w Kielcach
BlAkOSTOCKIE TEKl

HISTORYCZNE

TOM 16/2018

ISSN 1425-1930

DOI: $10.15290 /$ bth.2018.16.09

\title{
Przestrzeń miejska a uniwersytet jako przykład konfliktu społeczno-politycznego w Nowym Jorku i Berkeley, 1968-1969
}

Różnorodność i wielowarstwowość konfliktów społeczno-politycznych, jakie wystąpiły w Stanach Zjednoczonych w latach 60. widoczna jest chyba najlepiej na przykładzie rozumienia rzeczywistości przez pokolenie urodzone przed i po II wojnie światowej. W przypadku tego pierwszego doświadczenie wielkiego kryzysu gospodarczego i ciężkich czasów II wojny światowej kazały kierować uwagę na zachowanie i pielęgnowanie status quo w obawie, że jego zmiana doprowadzić może do zaprzepaszczenia awansu w każdym jego wymiarze - materialnym, zawodowym czy szeroko rozumianego miejsca w hierarchii społecznej. W przypadku pokolenia urodzonego w latach 1946-1964, zwanego umownie „baby boomers” to, co dla rodziców było punktem końcowym stało się w sposób naturalny początkiem ich przyszłości i kariery. Mając na uwadze linearny sposób myślenia Amerykanów, według którego przyszłość jest w naturalny sposób lepsza od teraźniejszości, stwarza warunki do rozwoju realizacji marzeń i stawiania nowych wyzwań - młodzi ludzie widzieli swój kraj jako miejsce $\mathrm{z}$ jednej strony, jako najlepsze $\mathrm{z}$ możliwych do ich spełnienia, ale $\mathrm{z}$ drugiej, jako niepozbawione wad i niesprawiedliwości. Jak jednak pokazywał przykład ruchu praw obywatelskich, skutecznie walczący o poprawę położenia czarnoskórej ludności Południa nawet największe przeszkody da się pokonać przy odpowiedniej determinacji, przekonaniu o nie tylko moralnej słuszności stawianych postulatów, dobrze zarysowanym programie i poparciu dotychczas środowisk biernych, ale wrażliwych na społeczną krzywdę i gotowych do jej naprawy. Zwycięstwo Johna F. Kennedy'ego w wyborach prezydenckich w 1960 r., najmłodszego ówcześnie wybranego na to stanowisko polityka wyzwoliło wśród młodzieży przekonanie, że czasy sprzyjają ich pokoleniu i że ma ona do odegrania wyjątkową rolę.

Wydany w 1962 r. Manifest Studentów na rzecz Demokratycznego Społeczeństwa, ujętej w organizacyjne ramy formy tego, co potem zaczęto określać jako Ruch (The Movement) lub Nowa Lewica uważał studentów za czynnik łamiący apatię w kampusach pełnych biurokracji, zmuszających do pogoni za oce- 
nami, konformizmem, społecznej apatii i niechęci do działania ${ }^{1}$. W życiu społecznym podkreślał konieczność naprawy problemów miast, takich jak przestępczość, choroby psychiczne, pogarszanie się warunków mieszkaniowych, odizolowanie od miasta, brak planowania przestrzeni miejskiej i wrażliwości na nią ze strony wielkich korporacji, pustoszenie i zamieranie centrów miast. „Wzorcowe miasto musi być projektowane, musi uwzględniać potrzeby miejscowych społeczności, rzeczywistą integrację klasową, mieć dostęp do przyrody, a jednocześnie szanować prywatność mieszkańców”, odznaczać się decentralizacją i społeczną kontrolą jego rozwoju i przeznaczanych na jego rozwój środków finansowych².

Czynnikiem zmian miała stać się młodzież i uczelnia. Dysponowała potencjałem wyrażającym się liczbą studentów ${ }^{3}$, rozumieniem miejsca szkolnictwa wyższego w społeczeństwie i jego ogromnego autorytetu społecznego w oparciu o wysoki poziom przekazywanej wiedzy wynikającej z połączenia angielskiej i szkockiej tradycji szkolnictwa na poziomie college'u, oraz przyjętych w drugiej połowie XIX w. niemieckich wzorców uniwersytetów badawczych. Uczelnie, zgodnie z jeffersonowskimi ideałami ograniczonej władzy federalnej, wolności słowa, przekonań i religii, pozostawiały kwestie wykształcenia wyższego w rękach fundatorów uczelni, a więc z dala od polityków i państwa. Wolność gospodarcza i swoboda w obrocie towarowym prowadziły do wniosku, że wiedza i wykształcenie także jest swoistym towarem, którego jakość można osiągnąć przez wymianę myśli, różnorodność i wysoki poziom nauczania do czego potrzebna jest przestrzeń zapewniająca ciągły rozwój. Uniwersytety cechowała niezależność, daleko idąca wstrzemięźliwość wobec władzy centralnej, krytyka posunięć rządu, ambicja, współzawodnictwo i zaangażowanie studentów w sprawy uczelni, a z czasem w kluczowe kwestie o zasięgu ogólnokrajowym.

Symbolem tych osiągnięć stał się stan Kalifornia i jego bezprecedensowy sukces po 1945 r. spowodowany splotem kilku czynników: ogromnego awansu gospodarczego związanego z rozwojem przemysłu maszynowego, stoczniowego, lotniczego, samochodowego i rolnictwa, niedrogiej ziemi, zachęcającej demobilizowanych żołnierzy do pozostania w nim na stałe i dużych możliwości zdobycia wykształcenia oferowanego przez ogólnostanowy system szkolnictwa zawodowego i wyższego symbolizowany przez Uniwersytet Kalifornijski. W 1947 r. miał on 8 kampusów (z Berkeley na czele), 43 tys. studentów, oferował bezpłatne

1 T. Hayden, The Port Huron Statement. The Visionary Call of the 1960s Revolution, New York 2005, s. 57-61.

2 Ibidem, s. 135-146.

3 W 1946 r. naukę we wszystkich typach szkół wyższych pobierało 2 mln studentów uczonych przez 165 tys. nauczycieli akademickich, w $1970 \mathrm{r}$. dane te wynosiły odpowiednio $8 \mathrm{mln}$ i ponad 500 tys. W 1946 studia magisterskie przyciągnęły 120 tys. młodych osób, w 1970 - 900 tys.; D. Ravitch, The Troubled Crusade. American Education 1945-1980, New York 1983, s. 183; szerzej J. R. Thelin, A History of American Higher Education, Baltimore and London 2004, s. $260-316$. 
nauczanie dla mieszkańców stanu, ogromne zasoby finansowe w postaci fundacji i zamówień z sektora rządowego, znakomitą kadrę profesorską i warunki nauki. Jeśli dodamy do tego inne ważne kalifornijskie uczelnie takie jak Stanford, California Institute of Technology, University of Southern California czy pozostałe kampusy Uniwersytetu Kalifornijskiego otrzymamy obraz stanu i uczelni tworzących swoisty rodzaj przemysłu wiedzy. Określenia tego użył rektor Uniwersytetu Kalifornijskiego Clark Kerr i zwrócił uwagę na fakt, że uczelnie przekształcają się w coraz bardziej złożoną strukturę, określając ją jako multiwersytet, przed którym stawia się zadania niespotykane w przeszłości. Jego uzasadnieniem, jak pisał, jest z jednej strony historia, a z drugiej spójność z oczekiwaniami społecznymi, gdyż pełnił nową i użyteczną rolę zmieniając się wewnętrznie i sam będąc motorem zmian. Jego miejsce powinno znajdować się na pograniczu obszarów gorzej i lepiej rozwiniętych dając w ten sposób studentom sposobność zetknięcia z biedą i ultranowoczesnością, a uczelni możliwość pracy na rzecz niwelowania tej pierwszej ${ }^{4}$.

Optymizm Kerra załamały wydarzenia z połowy lat 60 . Amerykańskie zaangażowanie $\mathrm{w}$ Wietnamie oraz raptowna zmiana społeczna wywołana przez ruch praw obywatelskich, ukoronowana przyjęciem ustaw o prawach obywatelskich i prawach do głosowania w latach 1964-1965, wywołała w społeczeństwie amerykańskim z jednej strony, nieśmiały początkowo sprzeciw wobec konfliktu w Azji Południowowschodniej, a z drugiej, obawy o przyszłość wciąż bardzo świeżych zmian. Dotychczasowe wartości uległy nagłej erozji, rodząca się kontrkultura zaczęła stawiać pytania o ich sens, przedmiotem krytyki stały się właściwie wszystkie dziedziny życia. Dotknęły one także architekturę i planowanie przestrzenne. Dyskusja w środowisku urbanistów sprowadzała się przede wszystkim do zakwestionowania charakteru powstających masowo po wojnie przedmieść. Podkreślano wprawdzie ich egalitarny charakter, ale zarzucano również jednostajność, zuniformizowany charakter i brak wyrazu konkludując, że nie rozwijają mieszkańców oraz nie oferują żadnej przestrzeni, gdzie następowałaby ich integracja i tworzenie zaangażowanej wspólnoty, a tym samym nie stają się one miejscem budowania oddolnej demokracji. W miastach pojawił się niedoceniany wcześniej czynnik rasowy. Uchwalenie przez Kongres ustaw o prawach obywatelskich i prawie do głosu $(1964,1965)$ symbolizowało rozwiązanie problemu rasowego, ale nie uwzględniało różnicy pomiędzy ludnością biedniejszego i wiejskiego Południa i zamożniejszych miast Północy i Wschodniego Wybrzeża. Nawarstwiały się tam zupełnie inne problemy: dzielnice czarnych oddzielone od dzielnic białych kordonem rasowym i ekonomicznym powodującym brak ru-

${ }^{4}$ C. Kerr, The Uses of the University, [w:] The University Crisis Reader. The Liberal University Under Attack, red. I. Wallerstein, P. Starr, New York 1971, s. 83-84; fragment przemówienia Clarka Kerra, Clark Kerr: Knowledge Industry, https://www.youtube.com/watch?v=_4J94a_NxLU [dostęp: 19.04.2017]. 
chliwości społecznej czy możliwości awansu stawały się klatką, z której nawet zamożniejszym trudno było się wydostać. Budowa szerokich ulic i tras szybkiego ruchu przecinających dzielnice prowadziła do ich szybszego rozbicia i degradacji społecznej i ekonomicznej. W Harlemie napływ Portorykańczyków w późnych latach 40. i 50. pogorszył i tak trudną sytuację - w połowie lat 60 . z zasiłków socjalnych korzystało $17 \%$ czarnych i $19 \%$ portorykańskich mieszkańców tej dzielnicy. Wyprowadzały się z niej oferujące pracę zakłady, zmniejszała się pomoc finansowa ze strony miasta. Niższe czynsze zachęcały białych nowojorczyków do kupowania tam mieszkań, a położony na styku białej i czarnej części Manhattanu Uniwersytet Columbia zaczął się rozglądać za niedrogą działką na powiększenie bazy lokalowej uczelni. Władze Nowego Jorku zachęcały również duże korporacje do inwestowania w biedniejsze obszary miasta licząc na polepszenie się panujących w nich warunków przez tworzenie miejsc pracy i napływ kapitału. Uczelnia prowadziła także wyburzenia biednych kamienic czynszowych i stopniowy wykup gruntów co do końca 1965 r. nie budziło sprzeciwu ponieważ terenami tymi miasto nie było zainteresowane $\mathrm{W}$ rezultacie czarni mieszkańcy tracili tanie miejsca zamieszkania, a uczelnia, gromadząc środki na inwestycje, czekała z zagospodarowaniem pustych przestrzeni ${ }^{5}$.

Przestrzeń miejska stawała się coraz bardziej podzielona i regulowana środkami własnościowymi. Apelowano więc, aby uczynić ją bardziej otwartą i przyjazną, przez wznoszenie gmachów służących różnym celom, unikanie wielkich bloków i generowanie jak najwięcej miejsca dla mieszkańców. Jane Jacobs, propagująca te idee, utrzymywała, że doprowadzi to do powstania różnorodności i wzajemnego poszanowania przez mieszkańców tych obszarów. Inne głosy wzywały do budowy infrastruktury służącej pieszym, tak aby przechodnie spotykali się i wchodzili ze sobą w interakcje. W ten sposób zaprojektowane tereny podlegałyby samoregulacji, wytwarzały własne prawa i zasady, poczucie bezpieczeństwa i swoisty koloryt. Szczególną rangę nadawano parkom konstruowanym w taki sposób, aby widoczna w nich była różnorodność przebywających tam osób. Miały być wielofunkcyjne, otwarte, położone na przecięciu ciągów komunikacyjnych oraz dysponujące małą architektury. Ich użytkownicy, korzystając zarówno z oferowanej przez nie przestrzeni i obecności innych, budowaliby oddolnie tkankę społeczną. W ten sposób nadawałaby ona godność miejscowej społeczności, stałaby się miejscem wyrażania poglądów i włączała do społeczeństwa marginalizowane dotąd grupy stając się czynnikiem ich awansu' ${ }^{6}$. Ten

\footnotetext{
5 S. M. Bradley, Harlem vs. Columbia University. Black Student Power in the Late 1960s, Urbana and Chicago 2009, s. 23-38.

6 Szerzej S. Tonnelat, The sociology of urban public spaces, https://www.academia.edu/313641/ The_Sociology_of_Urban_Public_Spaces, pdf, s. 2-4 [dostęp: 30.01.2017]; D. Mitchell, The End of Public Space? People's Park, Definitions of the Public, and Democracy, „Annales of the Association of American Geographers" 1995, t. 95, nr 1, s. 108-133; idem, The Right to the City. Social Ju-
} 
idealny stan francuski socjolog Michel de Certeau, nazwał zwycięstwem „słabych" nad „silnymi”".

Rosnące zapotrzebowanie na naukę i wyższe wykształcenie z jednej strony, cieszyło uniwersytety, ale z czasem stało się sporym obciążeniem. Radość wynikała z ciągle poprawiającej się sytuacji finansowej wynikającej z rytmicznie napływającego czesnego i rosnących zamówień rządowych. Uniwersytet Kalifornijski szczycił się opinią jednego z najlepszych w USA, uchodził za wzorzec masowej edukacji z budżetem 44 mln ówczesnych dolarów i darowiznami z różnych źródeł sięgającymi $40 \mathrm{mln}$ dolarów. Kalifornia wydawała najwięcej ze wszystkich stanów na edukację w przeliczeniu na głowę mieszkańca. Środki pochodziły także z badań zleconych przez przemysł lub Departament Obrony. Uczestnicząca w nich Columbia czerpała je od 1959 r. z zamówień Instytutu Analiz Obronnych (Instutute for Defence Anlyses, IDA) dysponującego budżetem $12 \mathrm{mln}$ dolarów ${ }^{8}$. Lecz z drugiej strony, uczelnie, chcąc sprostać ogromnej poplarności i wzajemnej konkurencji wymagały inwestycji w nowe gmachy, laboratoria, domy studenckie, sale gimnastyczne, a nawet parkingi. W $1952 \mathrm{r}$. Uniwersytet Kalifornijski w Berkeley zaplanował pozyskanie od miasta niezagospodarowanej i niewykorzystanej działki w sąsiedztwie kampusu. W 1956 r. podano, że uniwersytet wzniesie tam budynki administracyjne, pomieszczenia mieszkalne dla studentów i boiska sportowe, czemu sprzyjało położenie działki w niewielkiej odległości od głównego kampusu. Władze uczelni przypuszczały również, że nowe budynki korzystnie wpłyną na zamieszkałe przez studentów niskoczynszowe i raczej biedne domy z sąsiedztwa, mając nadzieję, że skłonią one młodzież do przeniesienia się do nowoczesnych akademików. W Columbii w 1958 r. rektor Grayson Kirk uzyskał zgodę zarządu parków miejskich na wydzierżawienie terenu o powierzchni niecałego hektara na wybudowanie na niej hali sportowej. Poza względami praktycznymi (brak hali przy zwiększającej się liczbie studentów stawał się uciążliwy, inne uniwersytety mogły pochwalić się znacznie lepszą infrastrukturą atrakcyjną dla sportowo zorientowanej młodzieży i położeniem w pobliżu głównego kampusu) uważano, że umieszczenie jej na terenie parku Morningside umożliwi korzystanie z niej okolicznej ludności, na co uczelnia chętnie przystała ciesząc się, że uzyskanie lokalizacji w parku

stice and the Right to the Public Space, New York - London 2003, s. 129-135; J. Jacobs, The Death and Life of Great American Cities, New York 1961, s. 90-111; T. Hoving, Think Big About Small Parks, „The New York Times" 10 April, 1966, http:/query.nytimes.com/gst/abstract.html?res= 9E04E0D81238E036A05753C1A9629C946791D6CF\&legacy=true

7 T. Davis, Designed Space vs. Social Space. Intention and Appropriation in an American Urban Park, [w:] Public Space and the Ideology of Space in American Culture, red. M. Orvell, J. L. Meikle, Amsterdam - New York 2009, s. 340-341.

8 J. R. Thelin, A History of American Higher Education, s. 286-287; Crisis at Columbia. Report of the Fact Finding Commission Appointed to Investigate the Disturbances at Columbia University in April and May 1968, New York 1968, s. 89. 
nie spowoduje konfliktogennych wyburzeń i przesiedleń mieszkańców. W 1961 r. uzyskano wymagane zezwolenia nakładające obowiązek rozpoczęcia budowy do końca sierpnia 1967 r. oraz dotację gubernatora stanu Nelsona Rockefellera. Sprzeciwów nie zgłaszała także opinia publiczna, choć część z harlemskich organizacji kwestionowała lokalizację ze względu na publiczną (miejską) własność działki wykorzystywanej przez prywatnego właściciela.

Jednak w połowie lat 60 . zaszły wydarzenia, których dalekosiężnych skutków nikt się nie spodziewał. W latach 1963-1964 poważne zamieszki na tle rasowym przeszły przez Birmingham, Savannah, Cambridge, Chicago i Filadelfię. Na wiosnę 1965 r. fala rozruchów wróciła na Południe, do Selmy w stanie Alabama. W sierpniu tego roku, w czasie interwencji policji na przedmieściach Los Angeles, funkcjonariusze w niezamierzony sposób użyli siły wobec przyglądającym się ich działaniom czarnoskórym. Skutkiem tego były zamieszki, które zniszczyły podmiejską dzielnicę Watts kosztem 35 mln dolarów strat, 4000 aresztowanych i 35 osób zabitych. W następnym roku zamieszki objęły Los Angeles, Chicago, Cleveland i Baltimore. Badająca ich przyczyny tzw. Komisja Kernera, powołana przez Prezydenta Johnsona w lipcu 1967 r. stwierdziła, że najczęstszymi przyczynami zajść była reakcja czarnych na postępowanie policjantów w czasie interwencji, bezrobocie, warunki mieszkaniowe, niski poziom edukacji, brak możliwości uprawiania sportu, szeroko pojęte praktyki dyskryminacyjne stosowane przez banki, sądy, urzędy państwowe i niewystarczające programy społeczne oferowane przez władze federalne i miejskie ${ }^{9}$. Nowy Jork ominęły wprawdzie zajścia na tym tle, ale narastanie niezadowolenia widoczne było już w czasie wyborów miejskich jesienią 1965 r. Starający się o wybór republikański i biały kandydat John V. Lindsay, wykorzystując opinię miejskiego komisarza ds. parków Thomasa Hovinga, stwierdził, że budowa hali sportowej przez Columbię jest szkodliwa społecznie ponieważ opinia miejscowej ludności została co do przyszłości parku zlekceważona, niezabudowane przestrzenie powinny pozostać nienaruszone i nie powinna z niego korzystać prywatna instytucja. Lindsay uważał halę za zbyt dużą i nieciekawą architektonicznie, a mieszkańcy Morningside za lekceważącą uznali opinię Davida Trumana, dziekana Columbia College, który stwierdził, że uniwersytet i tak zgodził się udostępnić zewnętrznym użytkownikom więcej miejsca w hali niż musiał. Dwa dostępne dla wszystkich piętra obejmowały $12 \%$ jej powierzchni ${ }^{10}$.

W 1966 r. atmosfera wokół hali zaczęła niepokojąco gęstnieć. W dzielnicowej i uczelnianej prasie pojawily się oskarżenia o rasizm ze strony uczelni, przejawiający się niskimi stawkami dla czarnoskórych pracowników, nielicznymi

\footnotetext{
9 Report of the National Advisory Commission on Civil Disorders, New York 1968, s. 143-157.

10 Crisis at Columbia, s. 79-80; L. Lasky, M.H. Lasky, Columbia. The Wound Unhealed, „Political Science Quarterly" 1968, t. 84. nr 2, s. 195-197.
} 
afroamerykańskimi wykładowcami i zarzutami o grabież ziemi ${ }^{11}$. W kwietniu miała miejsce demonstracja i ostre wystąpienia burmistrza Lindsay'a przeciw pracom nad wzniesieniem hali. Uczelnia z jednej strony zareagowała groźbą skierowania sprawy do sądu, z drugiej poszukiwaniem środków na rozpoczęcie budowy oraz propozycją dodania do jej publicznej części basenu i szatni. Uspokoiło to sytuację zaledwie na kilka miesięcy. Wiosną 1967 r. jej przeciwnicy zaproponowali, aby Columbia udostępniła całą halę mieszkańcom. Propozycja została przez władze odrzucona. W kwietniu miał miejsce kolejny protest przeciw jej budowie, powtórzony w lipcu i listopadzie tego roku ${ }^{12}$. Hasła wznoszone na wiecach były pełne gniewu, lecz liczba ich uczestników oscylowała wokół 100. W protestach brali także udział H. Rap Brown, radykalny działacz harlemskiego SNCC i senator stanowy Basil A. Paterson, wybrany z okręgu północnego Manhattanu, obejmującego Harlem ${ }^{13}$. Kontrowersje wokół budowy zwróciły uwagę zjazdu Studentów na rzecz Demokratycznego Społeczeństwa odbywającego się w Bloomington w dniach 27-31 grudnia 1967 r. i debatującego nad strategią i taktyką ruchu studenckiego w nadchodzącym roku. Jego uchwały, wskazując na klasowe uwarunkowania szkolnictwa wyższego, współpracę z korporacjami i nieliczenie się z interesami lokalnych społeczności, nawoływały do podjęcia walki czynnej z kompleksem militarno-przemysłowym wspólnie z klasą robotniczą i ruchami miejskimi od dnia 20 kwietnia $1968 \mathrm{r}$.

W Berkeley już w późnych latach 50. ulica Telegraph, wiodąca w stronę planowanych budynków stała się popularna wśród tamtejszej młodzieży. Oferowała przystępne cenowo pokoje do wynajęcia, księgarnie, kawiarenki, kluby i inne tego rodzaju miejsca, do których zaglądały także czołowe postaci z literackiego światka beatników z pobliskiego San Francisco. Trudno powiedzieć czy ich obecność miała wpływ na powstanie Ruchu na rzecz Wolności Słowa i strajk pod koniec 1964 r., faktem jednak jest, że na pewno nauczył on mło-

11 J. L. Avron, Up Against the Wall. A History of the Columbia Crisis, red. R. Friedman, New York 1969, s. 13-14.

12 CU CORE Pickets Against Park Site for proposed Gym, „Columbia Daily Spectator” (dalej: CDS) 1966, t. CX, nr 72, s. 1; CU Will Break Ground for Gym In October; Ignores Hoving Plea, CDS 1966, nr 73, s. 1; Gym Conflict Affects CU - Community Relations, CDS 1966, nr 74, s. 1; Ad Hoc Commettee Will Meet Hoving To Oppose CU Gym, CDS 1966, nr 81, s. 1; Renewal Council Opposes Gym and Seeks to Maintain SRO's, CDS 1966, nr 82, s. 1; Morningside Tenants Charge No Voice in Expansion Talks, CDS 1966, nr 90, s. 1; Hoving Reiterates opposition to Gym at Sunday Protest, CDS 1966, nr 104, s. 1-2; Propose State Bill to Block Gymnasium, CDS 1966, nr 108, s. 1, dodatek „Morningside Supplement” do „Columbia Daily Spectator” 1966, t. CXI, nr 49, s. S-1-S-3.

13 W gąszczu sprzecznych opinii, mnogości środowisk i rozbieżnych stanowisk władze Columbii straciły orientację i nie wiedziały jak i z kim kontynuować negocjacje, podgrzewane takimi np. wypowiedziami: „Jeśli wybudują pierwszą kondygnację wysadźcie ją. Jeśli wybudują trzy, spalcie je. A jeśli wybudują dziewięć zajmijcie je, są wasze, a potem może wpuścimy ich w weekendy"; J. L. Avron, op. cit., s. 19-20. 
dzież UCB organizacji, stawiania żądań i podejmowania działań. Położone po sąsiedzku San Francisco stało się w drugiej połowie dekady Mekką kontrkultury, hipisów i alternatywnego stylu życia. Jego sercem była dzielnica Haight Ashbury, skoncentrowana wokół butików, kawiarni i środków halucynogennych. Ściągający do niej artyści nadawali jej kolorytu, a tworzące jej esencję wspólnoty tworzyły przekonanie o realizacji utopii, jaką był samowystarczalny pod każdym względem świat, wolny od hipokryzji, egoizmu, konkurencji, opierający się na wszelkich swobodach i doznaniach obcych skostniałemu społeczeństwu. Dzieci-kwiaty widoczne były także w nieodległym Berkeley ${ }^{14}$.

W 1967 r. kanclerz UCB Roger Heyns przekonał zarząd uniwersytetu o konieczności inwestycji na pozyskanej od miasta działce i otrzymał na ten cel 1,3 mln dolarów z jego budżetu. Pod koniec roku rozpoczęło przejmowanie terenu i wyburzenia pod budowę gmachów administracyjnych, parkingu i boiska. W ostatnich miesiącach 1968 r. prace prowadzono nieregularnie i teren niszczał ${ }^{15}$. Pojawiły się plotki, że uczelnia wykorzystała na ten cel „środki studenckie"16, a spadająca liczba studentów korzystających z akademików czyniła argument rektora o konieczności wzniesienia nowych - bezprzedmiotowym ${ }^{17}$. Raptownie radykalizowało się także miasto i studenci. Wzmagał się opór przeciw wojnie wietnamskiej, mnożyły protesty młodzieży. Największe wrażenie wywarł jednak przywódca Partii Czarnych Panter Eldridge Cleaver, który po warunkowym zwolnieniu z więzienia za udział w strzelaninie w kwietniu 1968 r. wygłosił dwa miesiące później serię wykładów na uniwersytecie krytykując i bezpardonowo atakując gubernatora Reagana, a następnie wystartował w wyborach prezydenckich jako kandydat Partii Pokoju i Wolności. Pod koniec tego roku wybuchł strajk w San Francisco State College na tle rasowym - jego organizatorzy z Frontu Wyzwolenia Trzeciego Świata domagali się zorganizowania stałych zajęć o mniejszościach etnicznych w ramach odrębnego wydziału. Kiedy w styczniu 1969 r. protest przeniósł się na kampus Berkeley, gubernator ogłosił nadzwyczajny stan wyjątkowy, a władze uczelni zabroniły demonstracji w jej obrębie.

Kwestia planowanych inwestycji pozostawała na uboczu zachodzących konfliktów, jednak pod koniec 1968 r. sytuacja zaczęła się zmieniać. Przypuszczalnie w połowie $1968 \mathrm{r}$. narodził się w głowach aktywistów kontrkultury pomysł, aby

14 R. C. Cottrell, Sex, Drugs, and Rock'n'roll. The Rise of America's 1960s Counterculture, Lanham-Boulder-New York-London 2015, s. 117-154.

15 IA, Don Mulford Papers (DMP), Box 1, folder People's Park, Berkeley, General 1-16; The „People's Park”. A Report on a Confrontation at Berkeley, California, Submitted to Governor Ronald Reagan, Office of the Governor, State of California, July 1, 1969, s. 1-2.

16 Hoover Institution (HIA), Kenneth Gibson Fuller Collection (KGFC), Box 13, People's Park, folder 5, jednodniówka Radical Student Union pt. People's Park Crisis. Chronology. Setting, s. 1, July 29, 1969.

17 J. D. Cash, People's Park: Birth and Survival, „California History”. The Journal of the California Historical Society 2010, t. 88, nr 1, s. 9-10. 
przekształcić faktyczny nieużytek w ogólnodostępny park. Jak się wydaje zainteresowanie nim wywołał jeden z wykładowców architektury w Berkeley, który, uzyskawszy w lutym informację od władz uczelni o kontynuacji zawieszonych prac po 15 czerwca, podzielił się nią z zaprzyjaźnionymi działaczami, a ci, nie widząc wznowienia robót po tym dniu, postanowili przejąć teren, chcąc stworzyć na nim przestrzeń dla wszelkich alternatywnych działań. W grudniu miasto poprosiło o informację dotyczącą przyszłości terenu, sugerując przekazanie go na cel parku miejskiego ${ }^{18}$. Odpowiedź nie nadeszła, więc kierowani przez Michalea Delacoura działacze ogłosili 15 kwietnia 1968 r. zamiar przejęcia części uniwersyteckiej działki, założenia tam otwartego parku z placem zabaw, boiskiem, estradą i miejscem dla medytacji i wyciszenia duchowego, „centrum kultury, polityki, rapu i szaleństwa zachodniego świata”, będącego symbolem sprzeciwu wobec brzydoty i zaniedbania terenu przez uniwersytet. Entuzjastyczne poparcie spowodowało, że prace rozpoczęły się $20 \mathrm{kwietnia}^{19}$. Kilka dni później kontrkulturowe pismo „The Berkeley Barb” opublikowało duży artykuł na temat parku podkreślając spontaniczność działań, wspólne sadzenie kwiatów i drzew, tworzenie ogródków warzywnych, przygotowywanie posiłków. Organizowano pomoc dla budowniczych prosząc o użyczenie sprzętu budowlanego, narzędzi i żywności. Wzywano także do pomocy przy jego rozbudowie właścicieli spychaczy, proszono o przybycie z narzędziami budowlanymi, żywnością. W kolektywnym wysiłku widziano oddolną budowę demokracji i realnej władzy opartej na trudzie tworzących ją ludzi, co miało uczynić z parku ,prawdziwie socjalistyczne” osiągnięcie ${ }^{20}$. Tym samym uczelnia straciła kontrolę i nad terenem, i nad rozwojem wydarzeń.

Sytuacja w obu uniwersytetach osiągnęła groźny punkt. Kiedy protesty miały miejsce na terenie kampusu niezależnie od zewnętrznych uwarunkowań można było zakładać, że ich władze rektorskie przynajmniej do jakiegoś stopnia panują nad nimi i są w stanie na nie wpływać, lecz w chwili gdy wylały się one poza jego obszar nie było właściwie sposobów, aby je zatrzymać. Celem protestujących nie było już stworzenie parku czy wstrzymanie budowy hali, lecz zaatakowanie uczelni jako „,winnej” doprowadzenia do eskalacji sporu. Dla wielu studentów problem wojny wietnamskiej, urządzeń gimnastycznych, czy parkingu wydawał się na tyle odległy, że nie przyciągały ich nielegalne z punktu widzenia

18 The Bancroft Library (BL), CU 310.3, People's Park. Material assembled by the Center for Research and Development in Higher Education, 1969-70, Box 1, folder 10, list Kathellen Devaney to kanclerza Heynsa, z 18 grudnia 1968 roku; ibidem, folder 2, list wicekanclerza Earla F. Cheita do Sima Van der Ryna z 21 lutego 1968 roku.

19 Hear Ye, Hear Ye, „The Berkeley Barb” 1969, t. 8, nr 16 (192), s. 2. Pismo dostępne jest ze strony „The Independent Voices”, http://voices.revealdigital.com/cgi-bin/independentvoices?a=p\&p =home\&e=-------en-20--1-byDA-txt-txIN-fda-----------1 [dostęp: 30.01.2017].

20 J. D. Cash, People's Park, s. 12-15; HIA KGFC, Box 13, People's Park, folder 5, People's Park Crisis, s. 1; S. Albert, Free For All, „The Berkeley Barb” 1969, t. 8, nr 17(193), s. 5. 
władz Columbii lub Berkeley manifestacje. Kiedy jednak okazało się, że postulaty młodzieży spotykają się z oporem, celem ataku natychmiast stał się rektor, dziekan lub uniwersytet jako taki, ponieważ reprezentował on nie tylko władzę i system, ale przede wszystkim, będąc bliżej młodych ludzi, bardziej przemawiał do ich wyobraźni i podejmował działania bezpośrednio ich dotyczące. Dlatego park i hala sportowa jako przedmiot protestu zawęziły się do problemów odnoszących się bezpośrednio do sytuacji na kampusie, gdzie panować miał rasizm lub przemoc ze strony uniwersytetu. Miało to z punktu widzenia uczelnianych radykałów ogromne znaczenie, gdyż przyciągało niezdecydowanych studentów. Uczelnia stała się symbolem wyzysku, uprzedzeń rasowych, karierowiczostwa, żądzy zysku przez pracę dla Pentagonu, CIA i korporacji, a więc głównym celem ataku zrewoltowanej młodzieży ${ }^{21}$.

Wydarzenia w Columbii nie były jednak do końca splotem okoliczności. W grudniu 1967 r., w czasie posiedzenia komitetu krajowego Studentów na rzecz Demokratycznego Społeczeństwa, najważniejszego z radykalnych ruchów studenckich lat 60 ., wprost wskazano, jakie powinny być priorytety organizacji na nadchodzący rok. Miał to być przełom w walce ze Stanami Zjednoczonymi i wywołanie kryzysu politycznego przez masową akcję na uniwersytetach. Uchwała sygnalizowała niepowodzenia dotychczasowych działań i izolację, w jakiej znaleźli się ich inicjatorzy i nawoływała do podjęcia kroków mających silne umocowanie lokalne, ale odnoszących się do szerszych problemów społecznych. Uważano, że sukces może przynieść poszerzenie bazy protestu, stąd silne odwołania i pooszukiwania sojuszników poza uczelnią tak, aby znaleźć trwałe możliwości współpracy pomiędzy studentami a nie-studentami i wspólne źródła przemocy państwa wobec obu grup. W kilku przypadkach wskazywała ona wprost, które oddziały SDS powinny wykorzystać miejscowe napięcia, wśród nich Nowy Jork „Uniwersytet Columbia wykorzystuje wielki publiczny park na obszarze [etnicznego - W.B.] getta i buduje wielką halę sportową"22. Nie ma więc wątpliwości, że kwietniowy strajk nie był dziełem przypadku.

Uczelnia rozpoczęła budowę hali 19 lutego 1968 r. Kilka dni później, 22 i 23 lutego uniwersytecki dziennik ,The Columbia Spectator” zapowiedział demonstrację przeciwko kontynuacji prac i żądania ich wstrzymania, ale głównym motywem manifestantów były postulaty dotyczące zakończenia współpracy z IDA, prawa do publicznych przesłuchań studentów zatrzymanych $\mathrm{w}$ czasie jednej z wcześniejszych demonstracji i anulowaniu kar dyscyplinarnych dla jej

21 Fazy protestu zaobserwował i uogólnił John Searle, skądinąd umiarkowany zwolennik protestujących w Berkeley A Follproof Scenario for Student Revolts, [w:] The Radical Left. The Abuse of Discontent, red. W. P. Gerberding, D. E. Smith, Boston 1970, s. 161-171.

22 Program for a Spring Offensive. Resolution of the SDS National Council, December 1967, presented by N. Jaffe, J. Fuerst, and B. Gottlieb, The University Crisis Reader. The Liberal University Under Attack, red. I. Wallerstein and P. Starr, New York 1971, s. 139. 
uczestników. Między lutym a kwietniem sytuacja zaostrzyła się i SDS zintensyfikował zarzuty o rasizm, także w niewybrednej formie ${ }^{23}$. Mimo ostrzeżeń ze strony władz uczelni ${ }^{24} 23$ kwietnia 1968 miała miejsce nieudana próba wejścia do gmachu rektoratu, a przyłączenie się do protestujących grupy czarnoskórych studentów wzbudziło chwilową dezorientację białych organizatorów manifestacji, co spowodowało, że pod wpływem impulsu udała się ona na miejsce budowy hali, gdzie usiłowała przewrócić płot okalający wykopy i wdała się w krótkie przepychanki z interweniującą policją. Mark Rudd zażądał od przybyłego na miejsce jednego z dziekanów natychmiastowego przerwania robót i wycofania się z konsorcjum IDA, a kiedy nie usłyszał odpowiedzi poprowadził demonstrację z powrotem na kampus. Po krótkim przemówieniu Rudda ok. 450-osobowa grupa młodzieży weszła do Hamilton Hall, gdzie znajdowały się pomieszczenia dziekanatu i po kilku godzinach zamieszania przedstawiła 6 postulatów, wśród których na drugim miejscu widniało oczekiwanie zakończenia robót budowlanych hali sportowej. Protestujący zapowiedzieli, że nie opuszczą gmachu do czasu spełnienia ich żądań ${ }^{25}$.

Jednocześnie na terenie uczelni pojawiły się „,grupy z zewnątrz, z doświadczeniem $\mathrm{w}$ organizowaniu demonstracji połączonych ze stawianiem oporu, co było najprawdopodobniej świadomą decyzją podjętą w celu eskalacji sporu z administracją [uczelni - W.B.]". Byli to czarnoskórzy członkowie Kongresu na rzecz Równości Rasowej (CORE), Studenckiego Komitetu Koordynacyjnego Działań bez Przemocy (SNCC) i innych organizacji z pobliskiego Harlemu ${ }^{26}$. W późnych godzinach wieczornych między białymi studentami z SDS a członkami CORE i SNCC doszło do konfliktu. Młodzież z SDS została wyrzucona z Hamilton Hall i podjęła decyzję o okupacji gmachu rektoratu Low Library. W tym momencie strajk, choć nadal toczył się pod hasłami zawartymi w sześciu postulatach, przyjął kierunek wskazany przez grudniową uchwałę kierownictwa SDS. Jednak dla studentów nadal okupujących Hamilton Hall Columbia uosabiała rasizm, o czym wyraźnie mówi ulotka z 4 postulatami z 24 kwietnia wydana przez tę grupę głosząca, że strajk cieszy się poparciem mieszkańców Harlemu, odbywa się przeciw zawłaszczaniu dzielnicy przez białą rasistowską

\footnotetext{
23 Walkout Disrupts Memorial to King, CDS 1968, t. CXII, nr 91, s. 1; wulgarny atak na rektora Graysona Kirka Up Against the Wall Motherfucker, It's a Stick-up, „Up Against the Wall” 1968, t. III, nr 1, 2. 1-2, https://exhibitions.cul.columbia.edu/exhibits/show/1968/item/5521 [dostęp: 17.07.2017].

${ }^{24}$ Columbia University Archives, Central Files, folder Student Picketing 2/1965-6/1969, pismo prorektora Davida Trumana do Marka Rudda z 23 kwietnia 1968.

25 Columbia University Archives (CUA) Protest and Activism Collection 1958-1999, Box 6, SDS, folder 40, ulotki Join Us!, Strike! It was only the Start!; ibidem, Box 6, Strike Coordinating Committee, folder 13; Crisis at Columbia, s. 104.

26 Crisis at Columbia, s. 106-107.
} 
uczelnię, mającą, mimo posiadania kilku wielkich gmachów w tej dzielnicy, apetyt na wzniesienie kolejnego. „Columbia dokonała gwałtu na umysłach czarnych mieszkańców przez tak zwane badania socjologiczne [pokazujące poparcie dla pomysłu budowy hali - W.B.] ${ }^{27}$. Instytut Badań Obronnych miał w tym przypadku marginalne znaczenie. Dyskryminacyjny charakter działań nowojorskiej uczelni pokazuje jeszcze mocniej broszura pt. Why We Strike wydana w maju przez Strajkowy Komitet Koordynacyjny, w którym inwestycja została nazwana po prostu „Gym Crow” ${ }^{28}$. Tym samym uniwersytet stracił kontrolę nad biegiem wydarzeń i musiał się dostosować do narzuconych przez protestujących haseł i problemów.

O ile protest nowojorski spotkał się z poparciem radykalnych aktywistów miejskich, ale bierną na ogół reakcją większości mieszkańców Morningside, o tyle opinia publiczna Berkeley powitała ideę parku z zainteresowaniem i sporym poparciem. Na przełomie kwietnia i maja 1969 r. zebrano około półtora tysiąca podpisów przeciwników budowy boisk i zgody na stworzenie parku. Cieszył się on nawet opieką boską. 11 maja jeden z pastorów Wolnego Kościoła Berkeley, Richard York, widząc w szerokiej chęci jego stworzenia obywatelskie zaangażowanie na rzecz dobra i wspólnoty i przypuszczalnie przeczuwając nadchodzącą konfrontację, pobłogosławił miejsce udzielając mu poparcia całą mocą swojego kontrkulturowego kościoła ${ }^{29}$.

W komplikującej się coraz bardziej sytuacji mediacji między uczelnią a zwolennikami parku podjął się profesor Sid Van der Rynn, przewodniczący uczelnianej komisji ds. mieszkaniowych. 7 maja spotkał się z kanclerzem Heynsem argumentując, że kontrowersyjny teren podupadł i pozostawienie go w rękach młodzieży nie tylko doprowadzi do rewitalizacji działki, ale także zajmie czymś jego niechętnie widzianych użytkowników i będzie przejawem otwartości uczelni na zachodzące w przestrzeni społecznej zjawiska. Uczelnia odrzuciła jego poglądy twierdząc, że cała sytuacja powoduje wzrost przestępczości w okolicy kampusu, a uniwersytet ,nie jest od rozwiązywania problemów społecznych”30. Jednak 9 maja rektor poprosił Van der Ryna o przygotowanie w ciągu kilku dni

27 Our Demands. Leaflet from Black Students in Hamilton Hall, Columbia University, April 24, 1968, The University Crisis Reader, t. 1, s. 161-162.

28 „Gym Crow”, ibidem, s. 162-164. Tytuł to gra słów, nawiązująca, ze względu na identyczną wymowę, do postaci Jima Crow, stworzonej przez Thomasa D. Rice'a na podstawie postaci czarnoskórego spryciarza, popularnego w ludowych piosenkach i masowej wyobraźni na Południu USA, która z czasem nabrała ironicznego i pejoratywnego wydźwięku, funkcjonując także w zbitce Jim Crow Laws, oznaczającej dyskryminacyjne i segregacyjne prawa, którym podlegali Afroamerykanie.

29 HIA, KGFC, Box 13, folder 5, plakat Berkley Libration Program; ulotka An Open Letter to Chancellor Heyns from the Berkeley Free Church.

30 BL, CU 310.3, The People's Park, Box 1, folder 10, Sim van der Ryn, Building a People's Park, s. 14-18. 
planu rozwiązania sytuacji ${ }^{31}$ licząc, że przeprowadzone dzień wcześniej prośby o opuszczenie terenu i rozmowy ostrzegawcze z przywódcami młodzieży odniosą skutek $^{32}$. Van der Rynowi udało się wstrzymać prace przy parku do 1 lipca ${ }^{33}$. Jednak oczekiwania uczelni były, zdaniem młodzieży, zbyt daleko idące, dlatego nie zgodziła się na wyłonienie spośród siebie komisji negocjacyjnej i nie przerwali prac $^{34}$. Kanclerz uznał to za odmowę negocjacji i zapowiedział wzniesienie ogrodzenia, wstrzymanie prowadzonych na dziko prac, opracowanie nowego, kompromisowego planu zagospodarowania i wprowadzenie go w życie po wyjaśnieniu wszystkich wątpliwości i problemów prawnych. Uwzględniać on miał budowę boisk baseballowych, piłkarskich, do siatkówki i koszykówki i placu zabaw dla dzieci studentów, a także pozostawienie elementów wzniesionych przez młodzież pod warunkiem ich przydatności ${ }^{35}$. Zdecydowaną postawę kanclerza tłumaczyć można kilkoma powodami: przekonaniem o słabej pozycji Berkeley i jego samego w systemie Uniwersytetu Kalifornijskiego, obawą przed powtórzeniem się strajku z 1964 r. i ustąpieniu ówczesnego kanclerza Stronga oraz przypuszczalnie gwałtowną reakcją Ronalda Reagana, zasiadającego z urzędu w zarządzie i jego obecnością na posiedzeniu władz uczelni planowanym na 16 maja $^{36}$.

Zajęcie Hamilton Hall stanowiło spory sukces, ale w nocy z 23 na 24 kwietnia 1968 doszło do podziału między grupą SDS a czarnoskórymi studentami SAS i biała młodzież została wyproszona z gmachu. Dostała się następnie do pomieszczeń rektoratu i w kolejnym dniu okupowała już 5 budynków. Zaostrzenie sytuacji doprowadziło do zawieszenia zajęć i rozpoczęcia negocjacji, ale sprawa hali podnoszona była tylko przez studentów SAS - studentom z SDS chodziło przede wszystkim o wycofanie się z programu badań dla Departamentu Obrony i amne-

31 Van der Ryn zasugerował, aby uczelnia zachowała prawa do terenu dzieląc go na park i boiska, co podobało się młodzieży. Mieszkańcy opowiadali się za jego dzierżawą przez odrębny podmiot i przekształcenie go w ogólnodostępny park. Problemem był jednak hałas, nieporządek, sanitarne zanieczyszczenie parku i spodziewane interwencje policji, czego obawiała się uczelnia; J. D. Cash, People's Park, „California History” 2010, t. 88, nr 1, s. 19-20.

32 HIA, DMP, Box 1, folder People's Park, Berkeley, General 1-16, „The People's Park, A Report”, s. 7; The Bancroft Library; CU 310.3, The People's Park, Box 1, folder 2, pismo kanclerza Rogera Heynsa do Sima van der Ryna z 9 maja 1969; The Bancroft Library; CU 310.3, The People's Park, Box 1, folder 10, Sim van der Ryn, Building a People's Park, s. 6-9

33 Sin Van der Ryn, Building a People's Park, s. 14.

34 Uniwersytet oczekiwał, że park będzie pełnił jedynie funkcje rekreacyjne zgodne z potrzebami UCB, powinien być bezpieczny i nie wykorzystywany do innych celów, a także podlegać kontroli uczelni; BL, CU 310.3, The People's Park, Box 1, folder 10.

35 Ibidem, folder 2, oświadczenie kanclerza Haynesa z 13 maja 1969.

36 System Uniwersytetu Kalifornijskiego powstał w 1919 r. W 1969 r. miał on 9 niezależnych uczelni pod kierownictwem kanclerza nadzorowanych przez 24-osobowy zarząd (Radę Regentów). Roger W. Heyns był kanclerzem Berkeley od 1965 r.; J. D. Cash, People's Park, s. 20; stosunek gubernatora do szkolnictwa wyższego Kalifornii Gerard J. de Groot, Ronald Reagan and Student Unrest In California 1966-1970, „Pacific Historical Review” 1996, t. 65, nr 1, s. 107-129. 
stię dla uczestników tego i poprzednich protestów, a wykładowcom o niedopuszczenie do eskalacji protestu, zablokowania uczelni i użycia policji przeciw strajkującym $^{37}$. Profesorowie powołali Nadzwyczajną Grupę Pracowników Naukowych (Ad Hoc Committee Faculty Group, AHFG), proponującą z jednej strony, wstrzymanie prac przy hali i stosunkowo łagodne środki represyjne wobec strajkujących z drugiej. Wielodniowe negocjacje między SDS/SAS rektorem Graysonem Kirkiem a AHFG nie doprowadziły do osiągnięcia kompromisu ${ }^{38}$. Kiedy jego warunki zostały odrzucone, nie bez ingerencji ze strony czarnych radykałów H. Rapa Browna i Stokeleya Carmichalea ${ }^{39}$ rektor Kirk postanowił zezwolić policji miejskiej i uniwersyteckiej na usunięcie strajkujących siłą. 30 kwietnia funkcjonariusze wkroczyli do zajmowanych przez studentów pomieszczeń zatrzymując, według ustaleń komisji Coxa 692 osoby, studentów i absolwentów, a także kilku okolicznych mieszkańców; w starciach i przepychankach rannych zostało 100 osób $^{40}$. Choć na ręce rektora napłynęła ogromna liczba listów z poparciem dla jego działań ${ }^{41}$ to akcja policji spotkała się z gwałtownym sprzeciwem i oskarżeniami ze strony młodzieży przyglądającej się działaniom policji w budynkach, gdyż ta, bez powodu i ostrzeżenia zaatakowała obserwujących. Skutkiem tego był drugi strajk, mający o wiele większe znaczenie niż okupacja 5 budynków, obejmujący także profesorów i będący spontaniczną reakcją na działania policji. 23 maja doszło do ponownej okupacji gmachu rektoratu i policja ponownie wyprowadziła demonstrantów, tym razem jednak bez użycia siły. Do zajść doszło przed budynkiem Low Library, gdzie młodzież zaatakowała interweniujących funkcjonariuszy. Próbowano wzniecić ogień w kilku budynkach, wybito kilka szyb. Siły porządkowe użyły pałek, aresztowano 174 osoby, 68, w tym 17 policjantów, było rannych. Rektor Kirk zawiesił zajęcia, uczelnia została zamknięta, na jej teren wpuszczano tylko studentów i pracowników za okazaniem legitymacji. Uniwersytet praktycznie przestał funkcjonować ${ }^{42}$.

37 Crisis at Columbia, s. 112-113, 208.

38 CUA, Protest and Activism, Box 8, folder 1, pismo przedstawiciela profesorów Josepha L. Blau'a do Edwarda McMenamina, sekretarza uniwersytetu, z 24 kwietnia 1968; Faculty Reccommends Halt to Gym Construction, Campus Closed Down, SDS Holds Kirk Office, CDS 1968, t. CXII, nr 102 .

39 Negotiations Over Tri-Partite Body Tenuous; Brown and Carmichael Appear at Hamilton, CDS 1968, t. CXII, nr 104.

40 CUA, Protest and Activism, Box 1, folder 8, President Kirk - Correspondence, Police Arrest List, pismo Roberta Bookharta do rektora Kirka z 4 maja 1968; Crisis at Columbia, s. 142, University Call in 1,000 Police to End Demonstration As Nearly 700 are Arrested and 100 Injured; Violent Solution Follows Failure of Negotiations, CDS 1968, t. CXII, nr 107.

41 CUA, Protest and Activism, Box 1, folder 8, President Kirk - Correspondence, pismo Harolda Emersona do Graysona Kirka z 16 sierpnia 1968 mówi, że na 4993 otrzymane listy 911 wyrażało oburzenie na działania rektora i policji.

42 D. Bell, Columbia and the Left [w:] Confrontation: The Student Rebelion and the Universitites, red. D. Bell, I. Cristol, New York and London 1969, s. 89-90. 
W Berkeley kanclerz Heyns starał się wykazywać zrozumienie zwolenników parku, ale z drugiej strony rozumiał, że miejsce dla dalszych manewrów i uników kończy się. Jego pozycja nie była mocna ${ }^{43}$. Niechęć wzbudzali orędownicy budowy parku Arthur Lee Goldberg, Michael Delacour, Stewart Albert, William Crosby Miller i Frank Bardacke, wielokrotnie zatrzymywani za działalność polityczną ${ }^{44}$. Kolportowane ulotki pokazywały park jako konflikt ,przemysłowej machiny uniwersytetu i kultury rewolucyjnej”, walkę „o prawa, przestrzeń, a obecnie o ziemię. Park jest potrzebny, aby żyć i rozwijać się, a w końcu potrzebne nam będzie całe Berkeley". Mobilizowały do stawiania oporu i groziły,,zniszczeniem własności uczelni wartej 5 milionów w razie odebrania nam terenu wartego 1300 tysięcy dolarów. Jeśli uczelnia spróbuje odzyskać teren buldożerami odpowiemy siłą" ${ }^{45}$. Park miał stać się obszarem szerzenia kultury rewolucyjnej, wyzwolenia kobiet, rozprzestrzeniania narkotyków, stworzenia rządu ludowego i socjalizmu w Berkeley i zniszczenia rasistowsko-kapitalistycznego systemu w sojuszu z innymi ruchami na świecie. Opinię publiczną niepokoiły zakłócenia prawa i aresztowania rosnące lawinowo od $1966 \mathrm{r}$. Za trzydniowe zamieszki z 26-29 czerwca 1968 r. obwiniano uczelnię, gdyż zezwoliła radykalnym aktywistom wiecować na jego terenie ${ }^{46}$. Gubernator Reagan uważał, że ,atmosfera uniwersytetu przyciągnęła ten rodzaj ludzi” i oczekiwał od niego bardziej stanowczej postawy ${ }^{47}$.

W tej atmosferze 13 maja 1969 r. kanclerz Heyns nakazał przejęcie terenu. Następnego dnia ogrodzono działkę, polecono opuszczenie jej przez osoby spoza uczelni i tłumacząc $\mathrm{w}$ oświadczeniu przyczyny takiej decyzji apelowano o zachowanie spokoju ${ }^{48}$.

Działania uniwersytetu spotkały się ze zdecydowanie wrogą postawą jego zwolenników. Postawione w środę 14 maja rano znaki zakazu wstępu na teren parku zostały wyrwane i spalone. W południe obrońcy parku wybrali swoich

\footnotetext{
43 Sid van der Ryn, Building A People's Park, s. 18-19.

44 A People's Park. A Report, s. 4-5.

45 HIA, Kenneth Fuller Collection, Box 13, folder 5, ulotka A Proclamation by Madmen.

46 Ibidem, Trockyist French Solidarity Rally and Riots, June 28-30, 1968. Peter Camejo, pismo Marvina Buchanana do radnego Dona Mulforda, z 2 lipca 1968; wycinki prasowe What The Radicals Want, „The San Francisco Chronicle” z 1 lipca 1968. Street Fighting in Berkeley, „San Francisco Examiner” z 2 lipca 1968; Berkeley Activists Face City Council, „Oakland Tribune”, z 2 lipca 1968.

47 „gotowość uczelni do zaakceptowania osób spoza niej jako uczestników demonstracji, o których wiemy, że nią kierują oznacza, że musi ona podjąć działania do zmiany atmosfery w kampusie"; ibidem, wycinek prasowy Reagan's Strong View on Berkeley, „San Francisco Chronicle” z 3 lipca 1968.

48 Bancroft Library, CU 310.3, People's Park, Box 1, folder 2, UCB Chancellor's Office, Oświadczenie kanclerza Rogera W. Heynsa z 13 maja 1969, s. 4; ibidem, oświadczenie kanclerza Rogera W. Heynsa z 14 maja 1969.
} 
przedstawicieli do rozmów z uczelnią i jeszcze raz publicznie przedstawili swoje argumenty. Obawiając się konfrontacji w sąsiedztwo parku skierowano prawie 300 policjantów. Następnego dnia rano siły porządkowe usunęły śpiące na jego terenie osoby i na nowo ogrodziły go.

W tej sytuacji zwołano wiec na godzinę 12, drukowano i kolportowano ulotki wzywające do obrony parku. „Ziemia należy do ludzi, którzy stworzyli jej piękno w postaci parku. Naszą miłością i wysiłkiem stworzyliśmy dla lokalnej społeczności wartość nie do oszacowania. Ich to nie obchodzi. Oni to niszczą" - głosiła jedna z nich. Inna oskarżała kanclerza o ochronę korporacyjnych interesów ${ }^{49}$, kolejna ironicznie prosiła o podlanie rosnących $w$ parku kwiató $w^{50}$, a jeszcze inna widziała $w$ działaniach uczelni odbieranie ziemi Indianom i wzywała do budowy miejsca dla „piękna, radości humanizmu w coraz bardziej zatrutym, posępnym, rygorystycznym, represyjnym społeczeństwie" ${ }^{51}$. Wolny Kościół Berkeley starał się nadać wydarzeniom nieco transcendencji: „Duch, który stworzył ten park, jest silniejszy od pałek i gazu, jest silniejszy nawet od uniwersytetów. Jako uczniowie Jezusa jesteśmy zdecydowani stanąć razem z biednymi i wyalienowanymi, tworzącymi nowy świat na pustych przestrzeniach starego" ${ }_{52}$. Kiedy grupa ok. 2000 wiecujących usłyszała ostre przemówienie Daniela Siegela obwiniającego za całą sytuację uczelnię ${ }^{53}$ udała się na teren jego budowy, gdzie doszło do starć z policją tak gwałtownych, że uzyskała ona pozwolenie na użycie broni śrutowej ${ }^{54}$. Zginęła także jedna osoba 25-letni James Rector ${ }^{55}$, co wywołało gniew zwolenników parku, doskonale widoczny w radykalizmie wezwań i apeli zamieszczanych w masowo kolportowanych ulotkach ${ }^{56}$.

49 HIA, Mulford Papers, Box 1, folder Berkeley 1-6, ulotka Don't Let Heyns Fence Us Out! Come to the Noon Rally, 15 maja 1969; por. HIA, Fuller Papers, Box 13, folder 5, ulotka Bulletin Police Pollute Park.

50 Ibidem, ulotka Back to People's Park. People's Park is Occupied.

51 Ibidem, Berkeley United Native Americans. We Want Our Park!

52 Ibidem, An Open Letter to Chancellor Heyns, May 15, 1969, From the Berkeley Free Church.

53 HIA, Mulford Papers, Box 1, Folder People's Park, Berkeley, General, 1-16, „If we are to win this thing it is because we are making it more costly for the university to put up the fence then it is for them to take down their fence. We (...) have to maximize the cost to them minimize the cost to us"; The People's Park. A Report, s. 15-16; W.J. Rorabaugh, Berkeley at War, s. 159-160; Siegel miał na myśli przede wszystkim koszty polityczne i przerzucenie odpowiedzialności za zaistniałą sytuację na uczelnię.

5448 zatrzymanych demonstrantów, 103 rannych policjantów oraz 43 rannych manifestantów; HIA, Mulford Papers, Box 1, folder People's Park, Berkeley, General, 1-16, The People's Park. A Report, s. 15-23.

55 Ibidem, s. 23. Obszerny materiał dotyczący Rectora, okoliczności śmiertelnego postrzału, fotografie i relacje świadków, a także szeroki opis demonstracji z punktu widzenia ich uczestników zamieścił „The Berkeley Barb”, Vol 8, No. 21, Issue 197 z 23-29 maja 1969.

56 HIA, Fuller Papers, Box 13, folder 5, ulotka Don't Park on the Blood. James Recotr Died; A Statement on the Troubles in Berkeley; ulotka Resist and Create; ibidem, ulotka Let A Thousand 
16 maja gubernator Ronald Reagan wysłał na pomoc oddziały Gwardii Narodowej, lecz mimo ograniczenia swobody zgromadzeń i zatrzymań 20 maja miała miejsce kolejna manifestacja z udziałem ok. 5000 osób. Nie będąc w stanie kontrolować tłumu policja wezwała na pomoc śmigłowiec, który rozpylił nad manifestantami gaz łzawiący. Zatrzymano 92 osoby. 22 maja, w czasie kolejnej fali zamieszek, zatrzymano 497 osób. Łącznie zatrzymano 768 osób, koszty działań policji obliczono na 50 tys. dolarów dziennie, a użycie Gwardii Narodowej do 2 czerwca kosztowało 764 tys. dolarów ${ }^{57}$. Napięcie opadło dopiero po 30 maja, kiedy pokojowa manifestacja mieszkańców Berkeley zakończyła tę dramatyczną fazę sprzeciwu wobec działań uczelni.

Jak więc zmieniła się przestrzeń publiczna w wyniku przedstawionych wyżej zajść? W przypadku nowojorskiej uczelni można mówić o sukcesie strajku, ponieważ na posiedzeniu rady nadzorczej Columbii 3 marca 1969 r. zapadła decyzja o całkowitej rezygnacji z tego pomysłu, mimo ostrych sprzeciwów części jej członków i absolwentów wskazujących, że w ten sposób przepadnie $7 \mathrm{mln}$ dolarów zebranych na ten cel. Inwestycyjny kierunek działań uczelni przeniósł się na zachodnią stronę Manhattanu, w okolice Parku Riverside nad rzeką Hudson. Ale w świetle późniejszej wypowiedzi Marka Rudda, który w październiku 1968 r. stwierdził, że ,hala to bzdura i nic nie znaczy dla nikogo" 58 domniemywać można, że był to jedynie chwytliwy pretekst dla nadania strajkowi planowanemu w zupełnie innym celu szerszego wymiaru społecznego, pozyskania zwolenników z zewnątrz, uwagi mediów i oddźwięku wśród młodzieży i przede wszystkim wzmocnienia ogólnokrajowych akcji protestacyjnych przygotowywanych przez SDS ${ }^{59}$. W przypadku Berkeley konflikt trwał przez następnych kilka lat, ponieważ uniwersytet nie zamierzał odstąpić od swoich planów. Jeszcze w czerwcu 1969 r. władze Berkeley planowały tam budowę boska i parkingu co doprowadziło do demonstracji w marcu 1971 r. W następnym roku, teren, pozostający wciąż w rękach uniwersytetu, wydzierżawiło miasto tworząc tam otwartą przestrzeń dla koncertów i innych imprez masowych. Jednak uniwersytet

Parks Bloom; The Bancroft Library, CU 310.3, People's Park, Box 1, folder 12, ulotka James Rector is Dead. We Must the City Down; apel Berkeley Coalition Initiates Boycott of Berkeley Businesses until Outside Police and National Guard Are Removed; ulotki Boycott Berkeley; The Fence is Still Up; ulotka life and Death.

57 Ibidem, ulotka Today... It's Academic Rally at 2:00; HIA Mulford Papers, Box 1, folder People's Park, Berkeley, General, 1-16, The People's Park. A Report, s. 25-27.

58 R. McCaughey, Stand Columbia. A History of Columbia University in the City of New York, New York 2003, s. 485-486; por. Mark Rudd, Symbols of the Revolution, [w:] J. L. Avron, Up Against the Wall, s. 291-297, hala wspominana jest zaledwie pięcioma słowami (s. 297).

59 M. Rudd, Underground. My Life with SDS and the Weathermen, New York 2009, s. 42-65 podkreśla mocno kwestię IDA i ogólnie rasizmu w USA wyrażonego zamachem na Martina Luthera Kinga, wyraźnie marginalizując kwestię hali (,wiedzieliśmy o rasistowskim traktowaniu przez Columbię mieszkańców [Morningside - W.B.], także jej czarnych i latynoskich pracowników”, ibidem, s. 51). 
nie odstąpił od swoich praw własności i razem z różnymi grupami aktywistów miejskich współzarządza parkiem, który jednak stał się miejscem spotkań bezdomnych i życiowo wykolejonych ludzi. Wydaje się, że gdy wygasła rewolucja lat 60., a jej uczestnicy odnaleźli miejsce w życiu, znikł zapał w jego tworzeniu i nie najlepszy stan, w jakim obecnie się znajduje dobrze odzwierciedla upływ czasu, zmieniające się wartości oraz idealizowanie tej bez wątpienia wyjątkowej epoki w historii Stanów Zjednoczonych.

Pozostaje także odpowiedź na pytanie, w jakim stopniu aktywność młodzieży mogła zmienić przestrzeń miasta na lepsze. O ile Columbia postanowiła zrezygnować z działki w parku Morningside, o tyle ani władze miasta, ani lokalna społeczność nie potrafiły zagospodarować wzbudzającego kontrowersje terenu. Obszar, do przełomu lat 1989/1990, kiedy udało się go zrekultywować kosztem 5 mln dolarów przez wybudowanie zbiornika wodnego, placu zabaw i nasadzenia drzew, pozostawał ogrodzonym nieużytkiem i ogromnym wykopem. Zmieniły go dopiero działania absolwentów uniwersytetu, pracujących nieodpłatnie nad projektem rewitalizacji i zbierających pieniądze na ten cel. W tym sensie można powiedzieć, że protest młodzieży odniósł pozytywny skutek i przestrzeń została zachowana w sposób umożliwiający korzystanie z niej wszystkim, ale nie wolno zapomnieć, że jego pierwotnym celem był atak na uczelnię, a nie obrona parku. Inaczej przedstawia się sytuacja w Berkeley, gdzie doszło do konfrontacji między dwiema wartościami i wizjami społeczeństwa: ułożonej, sformalizowanej i konserwatywnej z jednej strony, a pełnej ekspresji, swobody i nieograniczonego poszukiwania szczęścia z drugiej. Dla zwolenników Park Ludowy tworzył się oddolnie, wysiłkiem wspólnoty, dla niej samej, był zagospodarowany i otwarty na gości, uosabiając ideały i kontrkultury, i Ameryki. Przedmiotem sporu stał się także dlatego, że jego apologeci uważali go za teren nikomu nieodebrany, dziewiczy, a więc idealnie odpowiadający tworzeniu komunitarnej, harmonicznej społeczności. Obie strony sporu nie chciały zrezygnować ze swojego rozumienia przestrzeni publicznej i zapewne dlatego Park Ludowy nie jest dziś emanacją tego, o co tak mocno walczyli jego twórcy.

\section{Urban space and the university as an example of social and political conflict in New York and Berkeley, 1968-1969}

\section{Summary}

In the 1960s public space, alongside with other social problems, became one of the areas where conflicts and tensions which had accumulated in previous years were visible. The problem was not only its spatial development and the manner in which it was done, but also its availability for local communities. At the time of defragmentation of the American society and searching for access 
to places for everyone, it became a problem of not only social but also political nature, as it intensified at the height of a deep crisis of the American state institutions.

Examples of such tensions are youth protests against the activities of Columbia University in New York and Berkeley in 1968 and 1969, respectively. The universities intended to expand campuses at the expense of the areas, which, despite being wasteland, were significant to the strong counter-culture in Berkeley and the black population of the New York Morningside neighborhood, where the university is located. While in the case of the New York university the desire to build a sports hall resulted from the real needs and the need to expand the housing base, the case of Berkeley shows how delay and the incapability of making decisions translated into unexpectedly large and dramatically ended riots. The similarities between the protests in both universities can be seen in the aversion to large corporations, such as universities, the subject of the dispute (the area necessary for its development), a highly administrative and bureaucratic way of conflict resolution and its result - a strike, violent demonstrations and deaths. The main difference between the protests is the political focus visible in Columbia, consisting in the desire to provoke a sharp crisis in other universities, by carrying out an occupational strike to be a model for other universities and building an alternative community based on countercultural values, in the form of, open to all their manifestations, Berkeley People's Park. In a broader context, events in both universities can be interpreted as a symbolic clash between the old order and the new one, for which the dispute over public space was only a pretext in the struggle for recognition and acceptance.

Key words: Berkeley, New York, Columbia, university, public space, protest

\section{Bibliografia}

Avron J. L., Up Against the Wall. A History of the Columbia Crisis, red. R. Friedman, New York 1969

Bradley S. M., Harlem vs. Columbia University. Black Student Power in the Late 1960s, Urbana and Chicago 2009.

Cash J. D., People's Park: Birth and Survival, „California History”. The Journal of the California Historical Society 2010, t. 88, nr 1.

Clark Kerr: Knowledge Industry, https://www.youtube.com/watch?v=_4J94a_NxLU

Confrontation: The Student Rebelion and the Universitites, red. D. Bell, I. Cristol, New York and London 1969.

Cottrell R. C., Sex, Drugs, and Rock'n'roll. The Rise of America's 1960s Counterculture, Lanham-Boulder-New York-London 2015.

Crisis at Columbia. Report of the Fact Finding Commission Appointed to Investigate the Disturbances at Columbia University in April and May 1968, New York 1968. 
de Groot G. J., Ronald Reagan and Student Unrest In California 1966-1970, „Pacific Historical Review" 1996, t. 65, nr 1.

Hayden T., The Port Huron Statement. The Visionary Call of the 1960s Revolution, New York 2005.

Hoving T., Think Big About Small Parks, „The New York Times” 1966, April 10, http:/l query.nytimes.com/gst/abstract.html?res=9E04E0D81238E036A05753C1A9629C 946791D6CF\&legacy=true

Jacobs J., The Death and Life of Great American Cities, New York 1961.

Mitchell D., The End of Public Space? People's Park, Definitions of the Public, and Democracy, ,Annales of the Association of American Geographers” 1995, t. 95, $\mathrm{nr} 1$.

Mitchell D., The Right to the City. Social Justice and the Right to the Public Space, New York - London 2003.

Lasky M. H., Columbia. The Wound Unhealed, „Political Science Quarterly” 1968, t. 84. nr 2.

McCaughey R., Stand Columbia. A History of Columbia University in the City of New York, New York 2003.

Public Space and the Ideology of Space in American Culture, red. Miles Orvell, Jeffrey L. Meikle, Amsterdam - New York 2009.

The Radical Left. The Abuse of Discontent, red. W. P. Gerberding, D. E. Smith, Boston 1970.

Ravitch D., The Troubled Crusade. American Education 1945-1980, New York 1983.

Report of the National Advisory Commission on Civil Disorders, New York 1968.

Rudd M., Underground. My Life with SDS and the Weathermen, New York 2009

Thelin, John R., A History of American Higher Education, Baltimore and London 2004.

Tonnelat S., The sociology of urban public spaces, https://www.academia.edu/313641/ The_Sociology_of_Urban_Public_Spaces

The University Crisis Reader. The Liberal University Under Attack, red. I. Wallerstein, P. Starr, New York 1971.

Prasa

„The Columbia Daily Spectator”, 1966-1968.

„The Berkeley Barb”, 1969. 


\section{Źródła i materiały}





\section{Syberyjska saga rodziny Kuleszów - wywiad z Anną Domaradzką \\ Przeprowadzil, opatrzył wstępem i opracował Mariusz Puchacz}

W ostatnich dekadach XIX w. rozpoczęła się masowa emigracja zarobkowa z ziem polskich. Polacy emigrowali przede wszystkim do Ameryki Południowej i Północnej, a w szczególności - do dynamicznie rozwijających się Stanów Zjednoczonych. Często nie pamięta się jednak o tym, że nie brakowało i tych, którzy poprawę swojej sytuacji finansowej upatrywali w wyjeździe w głąb Rosji, w tym, na kojarzącą się głównie z miejscem zsyłek, Syberię ${ }^{1}$. Dom, jakim Syberia stała się dla tysięcy Polaków, w następstwie rewolucji bolszewickiej $1917 \mathrm{r}$. i krwawej wojny domowej zamienił się w swego rodzaju pułapkę. Z tym okresem w dziejach polskiej diaspory na Syberii i Dalekim Wschodzie związana jest ewakuacja i repatriacja polskich dzieci: sierot, półsierot, bezdomnych i tych w trudnym położeniu materialnym. Została ona zorganizowana przez Polski Komitet Ratunkowy utworzony jesienią 1919 r. we Władywostoku przez tamtejsze polskie organizacje. Na jego czele stanęli Anna Bielkiewicz, Józef Jakóbkiewicz i Wieńczysław Piotrowski. W latach 1920-1923, dzięki konsekwentnej pracy tych osób, jak i wielu ich współpracowników, ewakuowano z Syberii i Dalekiego Wschodu i przewieziono do Polski w trzech transportach blisko 900 dzieci. Pierwsza grupa, ewakuowana z Rosji w 1920 r., przez Japonię i Stany Zjednoczone dotarła do kraju w marcu 1922 r. Druga - została przewieziona drogą morską bezpośrednio z Japonii do Polski latem 1922 r. Ostatnia i zarazem najmniejsza grupa dzieci, została przewieziona do kraju koleją, dzięki pomocy władz sowieckich w styczniu 1923 r. $^{2}$ Przeprowadzenie tej zakrojonej na szeroką skalę akcji

\footnotetext{
1 Do wybuchu I wojny światowej na Syberię przyjechało kilkadziesiąt tysięcy Polaków: osób wykształconych (dla których możliwość rozwoju zawodowego i finansowego była na ziemiach polskich zamknięta), robotników, górników oraz rolników. S. Leończyk, Polskie osadnictwo wiejskie na Syberii w drugiej połowie XIX i na początku XX wieku, Warszawa 2017; Z. Łukawski, Ludność polska w Rosji 1863-1914, Wrocław-Warszawa-Kraków-Gdańsk 1978, rozdz. III.

2 Zagadnienie to jest znane dzięki pracy badaczy polskich i japońskich, w szczególności Wiesława Theissa. Zob. W. Theiss, Dzieci Syberyjskie: dzieje polskich dzieci repatriowanych z Syberii i Mandżurii w latach 1919-1923, Waszawa 1991; W. Theiss, T. Matsumoto, Dzieci Syberyjskie: pomoc Japonii dla dzieci polskich z Syberii, 1919-1922, Warszawa 2009.
} 
nie byłoby możliwe bez wsparcia wielu osób i instytucji, w szczególności zaś państwa japońskiego, Japońskiego Czerwonego Krzyża i Polonii amerykańskiej.

Zamieszczony poniżej wywiad z Panią Anną Domaradzką (z domu Kulesza) - wnuczką osadnika z Syberii i córką repatriowanego „dziecka syberyjskiego” jest świadectwem burzliwych polskich dziejów. Losy jej rodziny jak w soczewce ukazują wiele wydarzeń polskiej historii: masową emigrację zarobkową, zmagania z sowiecką Rosją, pomoc okazywaną rodakom przez amerykańską Polonię, życzliwy stosunek państwa japońskiego wobec niepodległej Polski czy trud codziennego życia w II Rzeczpospolitej.

Mariusz Puchacz

Wywiad został przeprowadzony 17 czerwca 2018 r. w Białymstoku

Mariusz Puchacz (M.P.): Kiedy Pani przodkowie osiedlili się na Syberii?

Anna Domaradzka (A.D.): Moja rodzina pochodzi z Podlasia. Była to wielodzietna rodzina, w której najstarsze dziecko zostawało na gospodarstwie, w domu, pozostałe musiały szukać pracy. W ostatniej dekadzie XIX w. rozpoczęła się budowa Kolei Transsyberyjskiej, co sprawiło, że wzrosło zapotrzebowanie na pracowników³. Mój dziadek, Aleksander Kulesza i jego brat Antoni, zdecydowali się skorzystać z tej możliwości i pojechali na wschód. Dziadek urodzony w 1876 r. podjął taką decyzję w wieku 20 lat. Najpierw pracował przy budowie odcinka Kolei Transsyberyjskiej w okolicach Czyty ${ }^{4}$, potem Harbina ${ }^{5}$ i dalej pojechał w stronę Błagowieszczeńska ${ }^{6}$. Dziadek zaczął pracę jako płatniczy na kolei, rozwoził pieniądze pomiędzy stacjami i wypłacał je pracownikom poszczególnych odcinków budowy. Był to dobry początek. Nie był to człowiek, który budował kolej, tylko pracował w usługach. Uzyskanie stałego dochodu

\footnotetext{
3 Budowę Kolei Transsyberyjskiej rozpoczęto w 1891 r. Miała ona połączyć europejską część Imperium Rosyjskiego z Dalekim Wschodem. Trasa wiodła do Władywostoku. Przy jej budowie pracowały setki polskich inżynierów, techników i robotników, w szczytowym momencie stanowiących ok. 18-20\% wszystkich pracowników. Z. Łukawski, op. cit., s. 68-69. Zob. także: Z. Lech, Syberia Polska pachnaca, Warszawa 2002, rozdz. 9; B. Orłowski, O polskim wkładzie w budowe Wielkiej Kolei Transsyberyjskiej, [w:] Polacy w nauce, gospodarce i administracji na Syberii w XIX i na początku XX wieku, red. A. Kuczyński, Wrocław 2007, s. 413-428.

4 Stolica obwodu zabajkalskiego, obecnie stolica Kraju Zabajkalskiego.

5 Harbin jest miastem ,założonym” przez polskiego inżyniera Adama Szydłowskiego w 1898 r. Znajduje się on na terenie północnych Chin, przez które na mocy układu rosyjsko-chińskiego z 1896 r. przechodziła kolej wschodniochińska. Dzięki temu skrótowi trasa Kolei Transsyberyjskiej była krótsza o prawie 900 kilometrów. Z. Lech, op. cit., s. 229-231.

6 Wówczas i obecnie stolica obwodu amurskiego. Błagowieszczeńsk nie leży na trasie głównej linii Kolei Transsyberyjskiej, lecz ok. $100 \mathrm{~km}$ na południe od niej. Jest z nią połączony odnogą kolejową, której budowa została zakończona w trakcie I wojny światowej.
} 


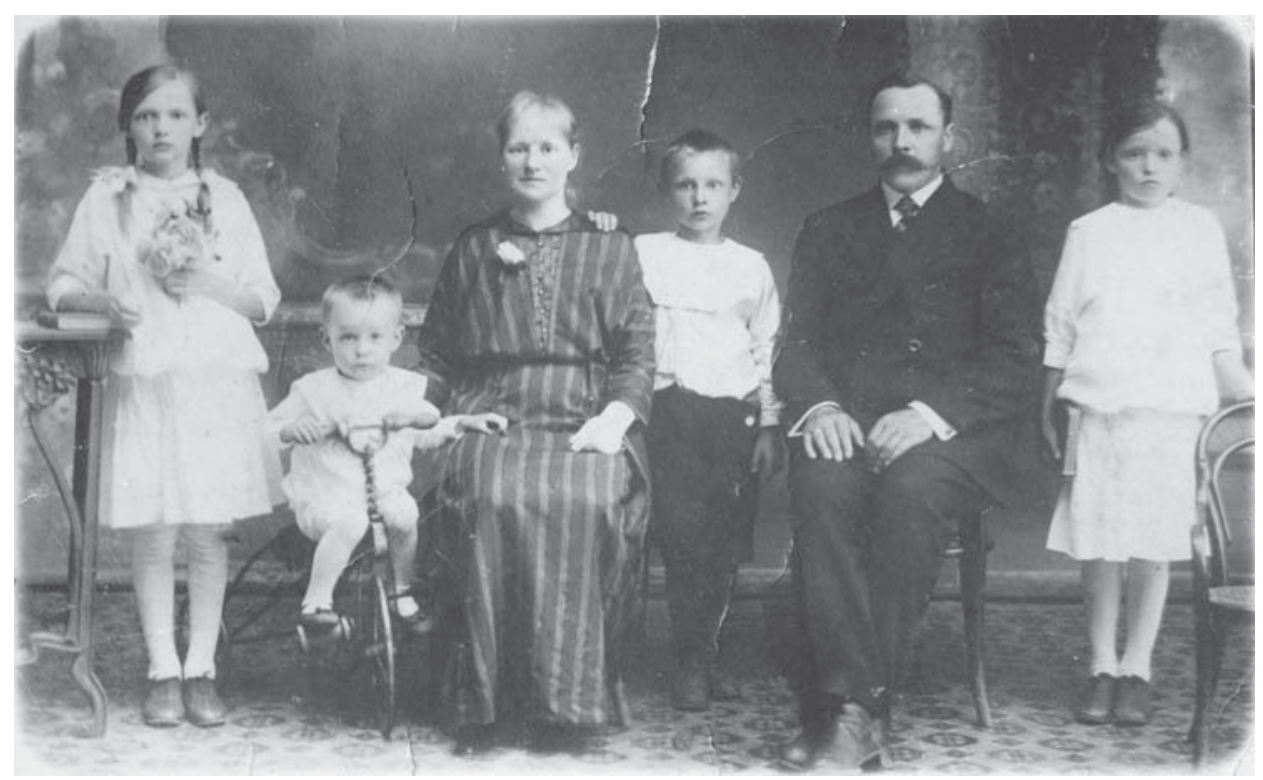

Rodzina Kuleszów, Syberia, ok. 1914 r. Kolejno od lewej: Czesława Lucja, Stanisław, Marcjanna (z d. Jabłońska), Leopold, Aleksander, Felicja. Zbiory rodzinne A. Domaradzkiej

umożliwiło mu poślubienie Marcjanny Jabłońskiej, pochodzącej z tych samych okolic Podlasia. Pobrali się gdzieś na trasie budowy Kolei Transsyberyjskiej, nie wiem dokładnie gdzie. Po ślubie urodziła się im czwórka dzieci, najstarsza córka, Łucja Czesława w 1904 r., druga córka Felicja w 1906, mój ojciec Leopold w 1908. Ta trójka dzieci miała zapisane w metrykach jako miejsce urodzenia stację Buchedu, niedaleko Harbina. Czwarte dziecko, Stanisław, urodziło się w 1913 r. w miejscowości Artieuszka, niedaleko Czyty. Co ciekawe, starsza córka została ochrzczona w Czycie, a mój ojciec w Harbinie. To są bardzo duże odległości pomiędzy tymi miastami, ale prawdopodobnie chrzest $w$ innych parafiach kościelnych i w innych miejscowościach związany był z przemieszczaniem się budowy kolei na wschód. Po kilku latach pracy na kolei, w 1913 r. dziadek zdecydował, że przeniesie się z całą rodziną na północ do Błagowieszczeńska, gdzie osiedlą się prawdopodobnie na dłużej.

\section{M.P.: Jak wyglądało życie Pani rodziny w Błagowieszczeńsku?}

A.D.: Dzieci chodziły do szkoły. Najpierw starsza ciotka uczęszczała do regularnej rosyjskiej szkoły podstawowej, a potem też młodsza i wreszcie mój ojciec. Starsza ciotka skończyła w Błagowieszczeńsku szkołę podstawową i cztery klasy szkoły średniej. Mój ojciec zaczął tam tylko szkołę podstawową, była to szkoła imienia Gogola, ale zdążył skończyć tylko trzy klasy, zanim zaczął się trudny okres zawieruchy rewolucyjnej i wojny domowej. 


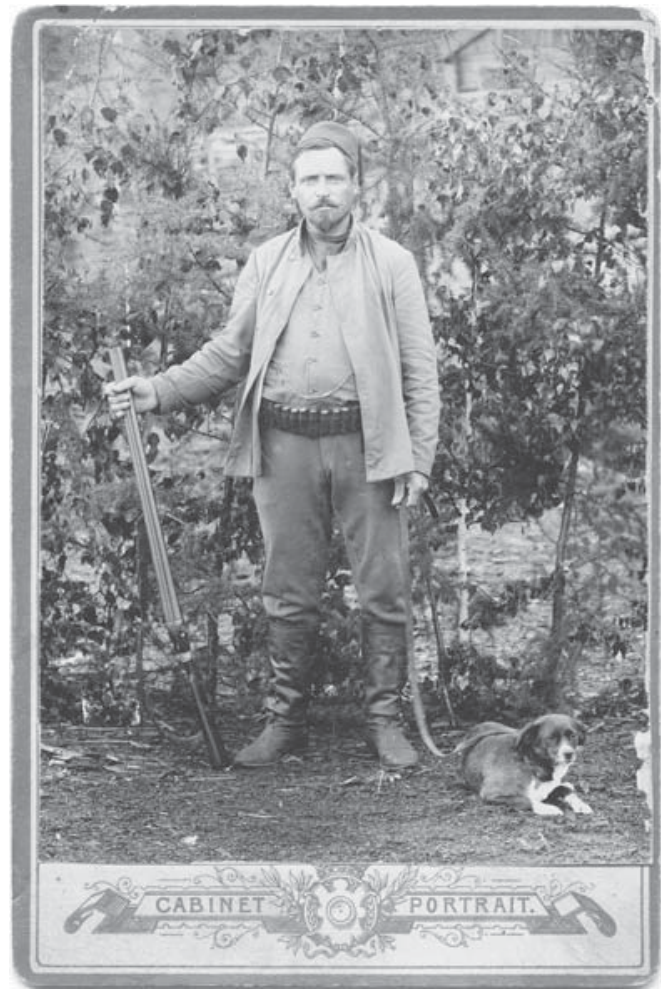

Włoski myśliwy Antonio Paskualini. Zbiory rodzinne A. Domaradzkiej

W Błagowieszczeńsku dziadek z babcią otworzyli jadłodajnię dla lokalnej ludności i pracowników budujących kolej. Raczej powodziło im się zupełnie dobrze. Tak jak ojciec opowiadał, zatrudniali dwóch myśliwych, którzy chodzili do tajgi polować na zwierzynę, taką jak kozły, dziki, sarny czy jelenie. Myśliwi ci byli Włochami, w zbiorach rodzinnych zachowało się zdjęcie jednego z nich. Dwa razy w tygodniu wychodzili do tajgi i przynosili świeżo upolowaną zwierzynę. Dziadek z babcią mieli takie olbrzymie drewniane beczki, w których solili i przyprawiali to mięso, aby móc je dłużej przechować. Zapotrzebowanie na nie było duże, ponieważ był to podstawowy produkt wyżywienia w czasie długich syberyjskich zim.

Babcia mając czwórkę dzieci w pewnym momencie zdecydowała, że potrzebują pomocy. Było dla niej już za trudno jednocześnie przygotowywać posiłki w stołówce, prowadzić księgowość oraz zajmować się dziećmi i domem. Ściągnęła z Podlasia swoją siostrę - Władysławę Jabłońską, która zajęła się przede wszystkim prowadzeniem księgowości. Z opowieści rodzinnych pamiętam, że to przedsięwzięcie rodzinne prosperowało zupełnie dobrze, także pod względem finansowym. Po pewnym czasie dziadek dostał stałą pracę w lokalnym państwo- 
wym banku w Błagowieszczeńsku. Został tam zatrudniony jako buchalter, było to zdecydowanie korzystniejsze dla całej rodziny. Babcia już wtedy nie musiała pracować; mogła zająć się tylko wychowaniem dzieci i domem. Stała praca dziadka dawała regularny dochód i pozwalała im prowadzić całkiem dostatnie życie. Wydaje mi się, patrząc na ocalałe rodzinne zdjęcia z tego okresu, że powodziło im się w miarę dobrze, wszyscy byli raczej zadbani, dobrze ubrani, a starannie gromadzone oszczędności finansowe rosły. Lepsza i ciekawa przyszłość była przed nimi, ale nadszedł rok 1917 i burzliwe lata rewolucji.

M.P.: W jaki sposób rewolucja zmieniła dotąd ustabilizowane i dostatnie życie Pani rodziny?

A.D.: Moja rodzina była aktywna w Domu Polskim? . Była to instytucja skupiająca lokalną Polonię, dzieci uczyły się tam języka polskiego, dodatkowo oprócz zajęć w regularnych rosyjskich szkołach. Polacy w Błagowieszczeńsku tworzyli zwartą kolonię, to byli ludzie zaprzyjaźnieni, którzy pielęgnowali polską

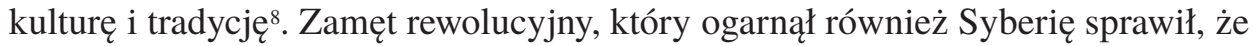
zaczęli myśleć o powrocie do ziemi ojczystej. Polacy, skupieni wokół Domu Polskiego postanowili napisać list do Polski, tak jak mi ojciec opowiadał, do Józefa Piłsudskiego. Mieli w nim opisać tragiczną sytuację kolonii polskiej w Błagowieszczeńsku i straszną rzeczywistość rewolucji w tej okolicy. Znaleźli łącznika, który miał przewieźć list do Warszawy. W okolicy Błagowieszczeńska płynie rzeka Amur ${ }^{9}$, która w tym miejscu ma ok. 3 kilometrów szerokości. Przedostający się przez tę rzekę wysłannik został złapany przez bolszewików. W konsekwencji służby sowieckie rozpoczęły poszukiwania osób, które podpisały się pod tym listem. Było ich ok. 20. Ksiądz Kamiński ${ }^{10}$, prowadzący tam polską parafię, został wezwany przez bolszewików, którzy powiedzieli mu, że jeśli zgodzi się na potwierdzenie nazwisk z tej listy, nie poniesie żadnych konsekwencji. Po kilku dniach ksiądz Kamiński zgodził się. Kiedy tylko potwierdził, że był współautorem listu i tożsamość pozostałych osób, które złożyły podpis pod pismem do Piłsudskiego, pierwszą rzeczą, jaką zrobili bolszewicy było aresztowanie księdza Kamińskiego i zorganizowanie procesu pokazowego dla wszystkich Polaków, których nazwiska były na tej liście. Wyroki były od kilku do kilkunastu

\footnotetext{
7 Domy Polskie, czyli instytucje kulturalno-oświatowe, zaczęły powstawać w Rosji dopiero po rewolucji 1905 r. Pierwszy powstał w Odessie, a kolejne w następnych latach na obszarze całego państwa, od Petersburga do Władywostoku. Zob. Z. Łukawski, op. cit., s. 146 i n.

8 Społeczność polska w Błagowieszczeńsku była stosunkowo liczna. W 1914 r. liczyła ok. 1000 osób. M. Kałuski, Polacy w rosyjskiej Mandżurii, „Studia Polonijne” 2001, t. 22, s. 135.

9 Amur jest rzeką graniczną, po jej południowej stronie znajdują się Chiny.

10 Ks. Władysław Kamiński, ur. w 1863, zm. w 1950 r. w Łabuniach koło Zamościa. Ukończył seminarium metropolitalne w Petersburgu, w 1892 r. przyjął święcenia kapłańskie. Wikariusz parafii w Tobolsku i Krasnojarsku w latach 1896-1898, następnie przez 20 lat proboszcz parafii w Czycie, skąd w 1917 r. trafił do parafii Przemienienia Pańskiego w Błagowieszczeńsku. A. Kijas, Polacy w Rosji od XVII wieku do 1917 r. Stownik biograficzny, Warszawa-Poznań 2000, s. 144.
} 
lat. Mój dziadek został skazany, tak jak mówił ojciec, na 8 lat więzienia ${ }^{11}$. I tak skończyła się dobra passa mojej rodziny. Dziadek w więzieniu, czwórka małych dzieci, a babcia bez możliwości ich utrzymania i wyżywienia, w skrajnej biedzie.

M.P.: W szczególnie trudnym położeniu znalazły się dzieci. Ich ratowaniem zajął się Polski Komitet Ratunkowy, którego przedstawiciele Wieńczysław i Władysław Piotrowscy, jesienią 1920 r. przybyli do Błagowieszczeńska. Pani dziadkowie zdecydowali się przekazać im swoje dzieci.

A.D.: To znaczy nie wszystkie dzieci. Tak jak mówiłam, dziadek był w więzieniu, babcia została sama $\mathrm{w}$ bardzo trudnym położeniu materialnym, w czasie rewolucji, gdy nie ma szacunku dla życia ludzkiego, a każdy człowiek, który pojawia się na horyzoncie może być wrogiem. Jak utrzymać czwórkę małych dzieci, skąd wziąć żywność, jak ubrać te dzieci, jak dać im możliwość przeżycia?

Dziadek z babcią otrzymali informację o przyjeździe do Błagowieszczeńska braci Piotrowskich z Polskiego Komitetu Ratunkowego we Władywostoku, prawdopodobnie z Domu Polskiego albo z polskiego kościoła. Wśród Polaków rozeszła się pogłoska, że można wysłać dzieci do Polski. Dziadkowie zdecydowali, że wyślą swoje dzieci, skorzystają z oferty, bo to jest prawdopodobnie jedyna szansa, żeby one przeżyły. Ale, co ciekawe, postanawiają wysłać tylko trójkę starszych dzieci, zostawiając najmłodsze dziecko z babcią. Ja teraz jako matka, widze jak nieprawdopodobnie trudna i odważna musiała być ta decyzja. Podzielić rodzinę, wysłać starsze rodzeństwo w nieznane i tygodniami, miesiącami nie wiedzieć co się z nimi dzieje. Jest obietnica, jest perspektywa, że dzieci przeżyją, ale nie wiem, czy oni tak faktycznie wierzyli, że to przedsięwzięcie wysłania dzieci do Polski przez Japonię i Stany Zjednoczone powiedzie się. Być może potrzebowali jakiejś ,,asekuracji”, dlatego tak na wszelki wypadek zostawili najmłodsze dziecko przy sobie, że jak ta akcja przesłania starszych dzieci do ojczyzny drogą dookoła świata nie wyjdzie, to może chociaż to najmłodsze przeżyje. Pomimo tego, że dziadek był ciągle w więzieniu, a babcia bez środków do życia, musieli przecież myśleć o lepszej przyszłości, chociażby dla dzieci. Tak jak mi później opowiadał już prawie osiemdziesięcioletni stryjek, właśnie ten mały wtedy chłopczyk, babcia musiała nawet żebrać, prosiła Rosjanki o pomoc. Okazuje się, że indywidualnie one bardzo babci pomogły, dawały żywność, jakieś ubrania, być może nawet schronienie i to wystarczyło na przetrwanie.

11 Tu zachodzi niezgodność, ponieważ według dokumentów urzędu zajmującego się wymianą więźniów politycznych Aleksander Kulesza został skazany na 6 lat więzienia ,,jako członek domu Polskiego w Błagowieszczeńsku za kontrrewolucję i działalność kulturalną w duchu narodowym Polskim". Zob. Personalja osób przeznaczonych przez Delegację Polska do Spraw Repatrjacji do wymiany personalnej z Rosji, załącznik do Pisma Mosdelpolu do Wardelpolu w sprawie zweryfikowanej listy „208” wymiany personalnej, 12 IX 1924, [w:] Wymiana więźniów politycznych pomiędzy II Rzeczpospolita a Sowietami w okresie międzywojennym. Dokumenty i materiaty, oprac. W. Materski, Warszawa 2000, s. 183. Ksiądz Kamiński również został skazany na 6 lat więzienia, ibidem, s. 181. 
I co jest niesłychane i zdumiewające to fakt, że dziadek wtedy otrzymał przepustkę z więzienia na przewiezienie dzieci do Władywostoku. I tak jak mój ojciec mówił, z obstawą, całą rodziną wraz z Wieńczysławem Piotrowskim i zebranymi przez niego innymi polskimi dziećmi pojechali pociągiem do Władywostoku, żeby wysłać starsze dzieci do Polski. Była to bardzo długa droga koleją, licząca tysiące wiorst ${ }^{12}$. Najpierw pojechali do Chabarowska, a z Chabarowska do Władywostoku ${ }^{13}$. Brat dziadka Antoni, który w tym czasie pracował w straży pożarnej w Szanghaju, powiadomiony o zamiarze wysyłki dzieci do Polski, przyjechał do Władywostoku, żeby spotkać się z rodziną. Wszyscy odnaleźli się na stacji Arteanskaja na przedmieściach Władywostoku. Był to taki rodzaj rodzinnego wsparcia i pomocy w tej, jakże trudnej emocjonalnie sytuacji. Tak jak ojciec później opowiadał, babcia ciągle płakała i płakała, bała się o przyszłość starszych dzieci wysyłanych w nieznane. Ten ból rozstania matki z dziećmi niewątpliwie był okrutny, trudny do pokonania. Było to też ostatnie spotkanie mego dziadka z jego bratem. Po przekazaniu dzieci na statek do Japonii wuj Antoni wrócił do Szanghaju, potem wszelki kontakt z nim już się urwał, zanikł. Natomiast mój dziadek wrócił do więzienia do Błagowieszczeńska.

Ojciec i jego siostry zostały przyjęte przez Polski Komitet Ratunkowy, choć tak jak później opowiadała ciotka Czesława Łucja, nie była wtedy pewna czy z powodu jej wieku nie zostanie odrzucona, miała wówczas 16 lat. Była jednym z najstarszych dzieci wysłanych do Polski ${ }^{14}$.

\section{M.P.: Kiedy Pani ojciec i ciotki opuścili Rosję?}

A.D.: W grudniu 1920 r. razem z innymi polskimi dziećmi z Syberii przepłynęli statkiem z Władywostoku do portu Tsuruga w Japonii. Tam, na kilka godzin trafili do lokalnej szkoły. Kilka lat temu odwiedziłam ten port i miasto Tsuruga, ta szkoła ciągle tam istnieje. Jeden z jej wychowanków pokazał mi

121 wiorsta $=1066,79$ metrów.

13 Piotrowski wspominał o tym w następujący sposób: „wreszcie 10 grudnia przeprowadzani przez p.p. Pokorskich, Rybaka, Jackowskich, Kuleszów i innych ruszyliśmy z westchnieniem ulgi do Chabarowska". W. Lazęga [Piotrowski], Sprawozdanie z wędrówki odbytej w sprawie ratownictwa dzieci polskich do kraju amurskiego, „Przegląd” [Harbin] 1921, nr 40, s. 7 (jest to druga część sprawozdania, pierwsza została opublikowana w numerze 39). Błagowieszczeńsk opuściło z Piotrowskim 21 dzieci. Do Władywostoku dotarli 30 grudnia.

14 Przyjęcie przez PKR osoby w tym wieku i wysłanie jej do Stanów Zjednoczonych było możliwe dzięki porozumieniu wypracowanemu w drugiej połowie listopada 1920 r. przez Jakóbkiewicza z organizacją finansującą transport i pobyt dzieci w USA, Wydziałem Narodowym Polskim (WNP). Zgodnie z nim Bielkiewiczowa mogła przysłać do USA dzieci ,niezależnie od wieku”. Telegram, Jakóbkiewicz i Smulski do Bielkiewicz, 24 XI 1920, Muzeum Polskie w Ameryce (MPA), WNP, sygn. 205. Przed osiągnięciem tego konsensusu WNP protestował przeciwko przysyłaniu młodzieży, przypominając, że ,prosiliśmy D-ra Jakóbkiewicza, aby dzieci starszych niż 12, a co najwyżej 14 lat tu nie przysyłano". Wilde do Lubomirskiego, 4 XI 1920, MPA, WNP, sygn. 205; także: Smulski do Targowskiego, 25 X 1920, ibidem; Wilde do Jakóbkiewicza, 26 X 1920, ibidem; WNP do Targowskiego, 27 X 1920, ibidem. 


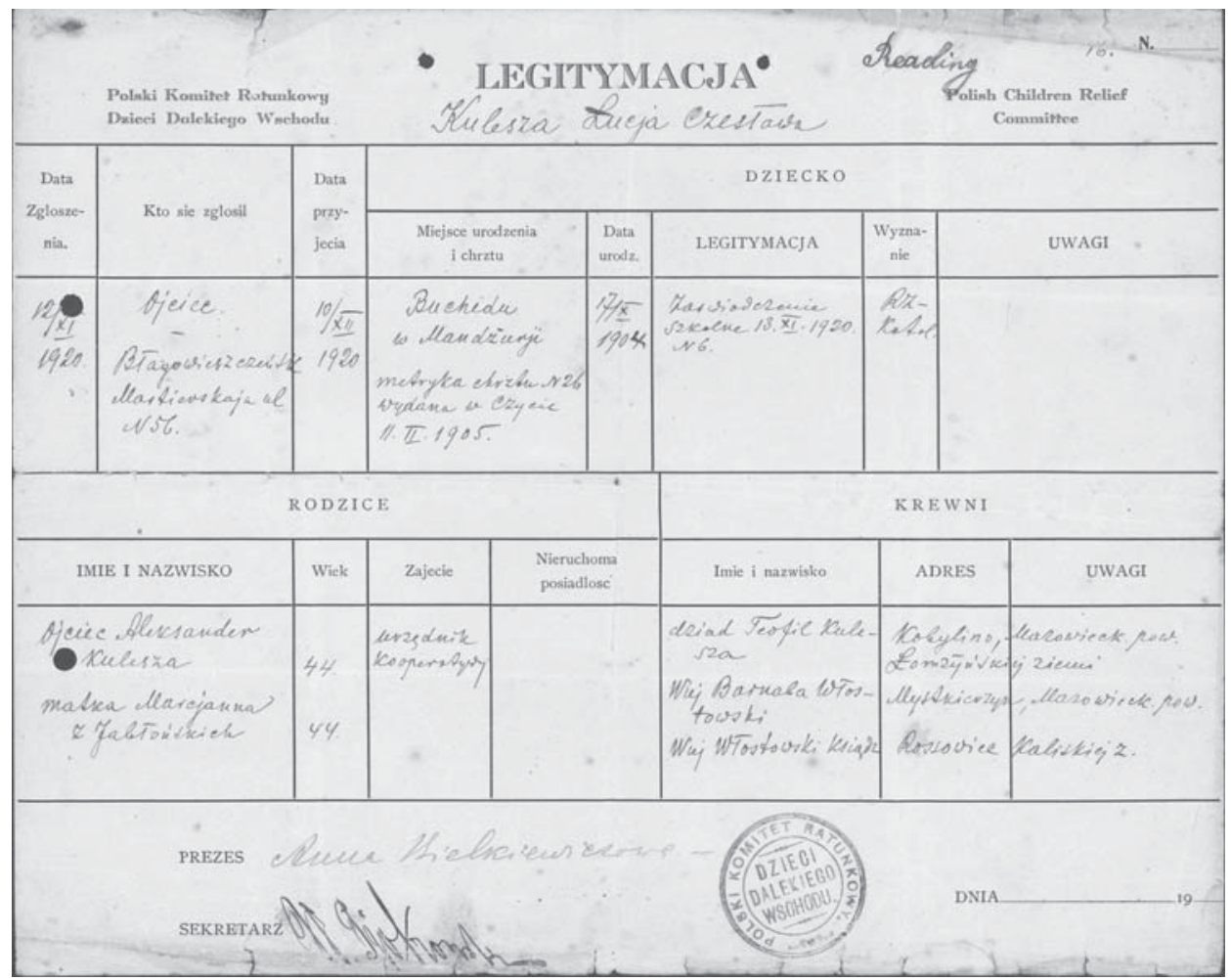

Legitymacja potwierdzająca przyjęcie Łucji Czesławy Kuleszy przez Polski Komitet Ratunkowy. Zbiory rodzinne A. Domaradzkiej

nawet budynek szkoły i powiedział, że ciągle w jej historii przypomina się, że uczestniczyli $\mathrm{w}$ akcji pomocy polskim dzieciom ${ }^{15}$. Z Tsurugi pociągiem dzieci przewieziono do Tokio. Zarówno w Tsurudze, jak i potem w Tokio, Japończycy zajęli się polskimi dziećmi bardzo życzliwie i serdecznie. Mój ojciec i jego siostry miały rodziców, jednak większość dzieci to były sieroty lub półsieroty, często chore, obdarte, głodne, niedożywione, zaniedbane, a nawet zawszone. Ewakuacja z Dalekiego Wschodu stwarzała tym dzieciom szansę na uratowanie i lepsze życie. Japończycy zajmowali się nimi bardzo dokładnie, dzieci musiały najpierw przejść kwarantannę i ze względów sanitarnych zostały pozbawione wszystkich swoich rzeczy. Japończycy przygotowali dla nich nowe, czyste ubrania, zabawki i słodycze.

15 W muzeum w Tsurudze znajduje się stała wystawa poświęcona ewakuacji polskich dzieci z Syberii i Mandżurii. Jest ona dostępna również w wersji internetowej: http://www.tmo-tsuruga.com/ kk-museum/index_e.html. 


\section{M.P.: Jak pobyt w Japonii został zapamiętany przez Pani ojca?}

A.D.: Po przyjeździe do Tokio, tak jak ojciec opowiadał, posadzono wszystkie dzieci przy takich maleńkich, niskich stoliczkach, dano im ryż i pałeczki, a one nie miały żadnego pojęcia jak się nimi posługiwać. To było dla nich zupełnie nowe doświadczenie. Ojciec zawsze podkreślał, że Japończycy byli dla nich bardzo dobrzy i serdeczni. Dużo uwagi i czasu poświęcali małym dzieciom, wozili ich na wycieczki, pokazywali lokalne buddyjskie świątynie, w szkole uczyli podstaw języka japońskiego, elementarnej matematyki, nowych zabaw dziecięcych, piosenek, wierszyków. Po latach, gdy byłam małym dzieckiem, ojciec też uczył mnie liczyć do dziesięciu po japońsku. Śpiewał mi także japońskie piosenki dziecięce typu „moshi moshi kameio”. To były chyba rzeczywiście jedne z najbardziej niezwykłych i pięknych miesięcy jego życia, które tak silnie zapisały się w jego pamięci. Do końca życia. Opowiadał także, że był jednym z tych polskich dzieci głaskanych przez japońską cesarzową, która odwiedziła ich w ośrodku Czerwonego Krzyża w Tokio wiosną $1921 \mathrm{r} .{ }^{16}$

Kiedy dorastałam, w okresie wczesnego dzieciństwa, w naszym domu rodzinnym był taki stary stół z szufladą. Mój ojciec miał tam mapy: starą mapę Polski, mapę Japonii, mapę Stanów Zjednoczonych i atlas świata. On je często wyjmował, otwierał i pokazywał mi miasta, w których już wcześniej był, które znał, gdzie się urodził, gdzie jest Japonia, gdzie są Stany. Po wojnie, w naszym domu, kiedy wszyscy słuchali Radia Wolna Europa, ojciec zawsze czekał na wiadomości i informacje o Japonii. Niezależnie od roli Japonii podczas II wojny światowej, ojciec darzył Japończyków wielką sympatią, wierzył w lepszą przyszłość tego kraju, wierzył w dobrych ludzi. Był im bardzo wdzięczny za okazaną pomoc. On też bardzo kochał przyrodę, zawsze opowiadał o pięknych drzewach japońskich, o sadach wiśniowych, o bujnej wczesnej wiosennej zieleni, o tym jak to wszystko tam wtedy pięknie kwitło. To, co on wcześniej zobaczył w Japonii, to było dla niego zawsze takie najładniejsze, najlepsze i bardzo ważne.

\section{M.P.: Kiedy dzieci zostały przewiezione do Stanów Zjednoczonych?}

A.D.: Dzieci przypłynęły statkiem z Jokohamy do Seattle w czerwcu $1921 \mathrm{r}$. Ojciec wspominał, że zeszli ze statku na ląd dopiero po dwóch czy trzech dniach, bo odprawa imigracyjna zajęła im więcej czasu niż się spodziewali. W Seattle przywitała ich miejscowa Polonia ${ }^{17}$.

\footnotetext{
16 Cesarzowa Teimei, księżna Sadako Kujō (1884-1951), żona cesarza Taisho.

17 W Seattle przyjęciem dzieci zajmował się powołany w tym celu Komitet Przyjęcia Dzieci Syberyjskich, współpracujący m.in. z Towarzystwem Domu Polskiego. Obecnie w Domu Polskim zawieszona jest fotografia przedstawiająca grupę dzieci syberyjskich. W pomoc zaangażowany był również miejscowy oddział filantropijnej organizacji Rycerze Kolumba.
} 
Dzieci zostały przewiezione z portu do Domu Polskiego na obiad i od razu tego samego dnia zostały wysłane pociągiem do Chicago ${ }^{18}$. W tym mieście również przywitała je lokalna Polonia, po czym dzieci zostały rozesłane do internatów i sierocińców w kilku stanach ${ }^{19}$. Po raz kolejny moja rodzina została podzielona. Obie ciotki trafiły do Reading w Pensylwaniii ${ }^{20}$, a ojciec z grupą ok. tuzina innych chłopaków, do New Britain w stanie Connecticut ${ }^{21}$. Ojciec został zakwaterowany w ochronce przyklasztornej i tam chodził do szkoły początkowej. Ciotki, ze znacznie większą grupą dzieci, trafiły do internatu. Wychowawcy i nauczyciele próbowali zapoznać dzieci z życiem amerykańskim. Najważniejsze było to, że dali im możliwość uczenia się podstawowych przedmiotów. Starsze dzieci, które były w okolicach Chicago trafiły lepiej, bo były przygotowywane do zawodu. Ojciec jeszcze był chyba na to za mały, miał ciągle tylko 12 lat. W Stanach Zjednoczonych dzieci spędziły prawie 8 miesięcy. Ojciec całe życie był w stanie powiedzieć kilka podstawowych zdań po angielsku, niemniej jednak po upływie lat już nie pamiętał zbyt dobrze tych wyuczonych zwrotów. W styczniu 1922 r. wszystkie dzieci zostały zebrane w Nowym Jorku i statkiem wysłane do Polski ${ }^{22}$. Statek ten nazywał się Princess Matoyka. Kilka dni po wypłynięciu z portu w Nowym Jorku na statku wybuchł pożar. Po ugaszeniu pożaru statek musiał wracać do Nowego Jorku, do naprawy, która zajęła dobrych kilka dni. Po jej ukończeniu statek ponownie wypłynął w kierunku Hamburga i Bremy.

M.P.: Jak potoczyły się losy Pani ojca i ciotek po przyjeździe do Polski?

A.D.: Moja rodzina po powrocie do Polski trafiła do Poznania. Ponieważ moje ciotki były jednymi ze starszych dzieci syberyjskich tego transportu, od razu zostały skierowane do szkoły handlowej w tym mieście. W trakcie nauki mieszkały na pensji. O ciotce Felicji nie mam zbyt dużo informacji, a starsza ciotka Łucja Czesława po skończeniu kursów handlowych pracowała w księgarni Gebethnera i Wolffa w Poznaniu. Po krótkim czasie pracy w tym mieście, obie moje ciotki zdały egzamin na 3 kurs seminarium nauczycielskiego w Wejhero-

\footnotetext{
18 Chicago było siedzibą Wydziału Narodowego Polskiego. Decyzją jego władz kierownik Szkoły Przemysłowej dla Sierot w Niles pod Chicago, ks. Franciszek Rush zajmował się rejestracją wszystkich dzieci przybywających do USA. Zob. Sprawozdanie z konferencji odbytej 22 X 1920, MPA, WNP, sygn. 205.

19 Łącznie do Stanów Zjednoczonych przywieziono 369 dzieci. 28 lipca 1921 r., po przybyciu ostatniego transportu Wydział Narodowy utrzymywał 355 dzieci. Przebywały one w ośrodkach w Connecticut (New Britain), Illinois (Niles), Michigan (Detroit), Pensylwanii (Cambridge Springs, Emsworth, Conshohocken, Reading), Wisconsin (Milwaukee, Polonia, Manitowoc). Rozmieszczenie i koszt utrzymania Dzieci Syberyjskich według stanu z dnia 28 lipca 1921, MPA, WNP, sygn. 205.

20 Sierociniec św. Franciszka.

21 Sierociniec św. Marii.

22 W USA z różnych względów pozostało 57 dzieci, 2 już wcześniej odesłano do krewnych do Polski, Dzieci, które pozostaja i z jakich przyczyn, MPA, WNP, sygn. 205.
} 
wie, zamieszkały w internacie prowadzonym tam przez Józefa Jakóbkiewicza ${ }^{23}$. Wcześniej naukę w Wejherowie rozpoczęła starsza ciotka, a w następnym roku młodsza. Natomiast mój ojciec z trójką innych kolegów został wysłany do szkoły ogrodniczej w Koźminie koło Poznania, którą ukończył po 3 latach. Mam nawet dyplom ukończenia przez niego tej szkoły. Po zakończeniu edukacji ojciec dostał zatrudnienie w ogrodach miejskich w Katowicach, jednak po kilku latach pobytu na Śląsku w związku z redukcją etatów został zwolniony i wyjechał na Podlasie do rodziny.

M.P.: Jak długo przebywał w sowieckich więzieniach Pani dziadek?

A.D.: Dziadek przebywał w więzieniu kilka lat. Po wojnie polsko-sowieckiej, rząd polski rozpoczął pertraktacje z sowietami dotyczące wymiany więźniów. W ramach jednej z wymian, dziadek jako więzień polityczny powrócił do Polski. Trudno mi wyjaśnić, jak to się stało, bo nie znam szczegółów. Niemniej, tak jak opowiadał później mój ojciec, dziadek pod konwojem dotarł do granicy w Stołpcach gdzieś w 1925 r. lub nawet już na początku 1926 r. ${ }^{24}$ Dziadek był bardzo szczęśliwy, przekraczając granicę ucałował polską ziemię. Mając prawie pięćdziesiąt lat, po ponad dwudziestu latach pracy na Syberii, na którą wyjechał z perspektywą poprawy życia, wrócił do Polski „bez niczego, bez żadnych pieniędzy. Tak jak wyjechał, tak wrócił”, jak wspominał ojciec. Skierował się w rodzinne strony, na Podlasie, tam skąd on i babcia pochodzili.

\section{M.P.: Kiedy do Polski powróciła Pani babcia?}

A.D.: Nie znam szczegółów, kiedy i w jaki sposób babci udało się powrócić z najmłodszym synem Stanisławem, wtedy już 12 lub 13-letnim chłopcem do kraju. Ale wróciła w rodzinne strony, do bliskich. Niestety, tragiczne warunki życia na Syberii odbiły się na jej zdrowiu, schorowana poruszała się już na wózku inwalidzkim. Zmarła w $1936 \mathrm{r}$.

M.P.: Powrót po wielu latach, po traumatycznych doświadczeniach był z pewnością trudny. Jak rodzina Kuleszów odnalazła się w nowej rzeczywistości?

${ }^{23}$ Zakład Wychowawczy Dzieci Syberyjskich w Wejherowie. Mieszkała w nim i uczyła się część dzieci syberyjskich. Funkcjonował w latach 1923-1929. Jakóbkiewicz był jego kierownikiem od chwili jego założenia, W. Theiss, op. cit., rozdz. VI.

24 Aleksander Kulesza znajdował się na „liście 208”, skupiającej Polaków więźniów politycznych w Związku Sowieckim przeznaczonych do wymiany za istotnych dla Moskwy więźniów polskich. Wymiana przeprowadzona w nocy z 31 I na 1 II 1925, jednak go nie objęła, na co wskazuje jego obecność wśród więźniów przebywających na Łubiance. Do Polski powrócił w ramach jednej z kolejnych wymian, trudno jednak ustalić, której dokładnie. Zob. Personalja osób przeznaczonych przez Delegację Polską...; Lista osób przeznaczonych do wymiany skoncentrowanych $w$ więzieniu wewnętrznym na Eubiance, 4 II 1925, [w:] Wymiana więźniów politycznych..., s. 206. Szerzej na temat wymiany więźniów politycznych W. Materski, Pobocza dyplomacji: wymiana więźniów politycznych pomiędzy II Rzeczapospolita a Sowietami w okresie międzywojennym, Warszawa 2002. 
A.D.: Jak już mówiłam, gdy mój ojciec utracił pracę w Katowicach, podążył w rodzinne strony na Podlasie. Moi dziadkowie wynajmowali wówczas dom w Sokołach, między Łapami a Wysokiem Mazowieckiem. Tam mój ojciec wraz dziadkiem i młodszym bratem, ponieważ miał już wyuczony zawód, otworzyli własny biznes, a mianowicie założyli szkółkę sadzonek drzew. Pracowali ciężko, dzierżawili sady, wynajmowali gospodarstwa i z czasem dorobili się jakiegoś tam zasobu finansowego. Po jakimś czasie za pieniądze otrzymane w wyniku sprzedaży szkółek drzew i za zgromadzone oszczędności kupili dom i działkę w Łapach, gdzie mieszkali już do końca życia.

M.P.: Jak Pani krewni wspominali życie w Rosji?

A.D.: O swoim życiu na Syberii opowiadali niechętnie i niezbyt często, zwłaszcza na początku. Zarówno obie ciotki, jak i mój ojciec o swojej przeszłości nie opowiadali zbyt chętnie, także dlatego, że - jak gdzieś wcześniej słyszałam - te dzieci, które trafiły do Wejherowa były nazywane „ruskimi”. Pewnie dlatego, że przybyły z odległej Syberii, z Rosji, ich język polski nie zawsze był poprawny, albo od czasu do czasu słychać było rosyjski akcent. Niemniej jednak to były bardzo patriotyczne polskie dzieci, ale w rezultacie spędzenia dzieciństwa na Syberii trochę ,inne”. Dzieci na Syberii chodziły do szkoły rosyjskiej, a więc rosyjski był ich pierwszym językiem. Polskiego uczyły się w domu rodzinnym i w Domu Polskim. Moja rodzina nigdy nie chciała być tymi „ruskimi”. To byli Polacy, dla nich najważniejsza była ich polskość. Swój rosyjski epizod moi krewni może nie tyle ukrywali, ile nie chcieli się nim afiszować ani specjalnie do tego wracać. I może dlatego nie chcieli też, żeby ktokolwiek słyszał ich mówiących po rosyjsku. Na przykład w naszym domu, jak ojciec czasami gotował, to przygotowywał nie naleśniki, ale jak się u nas mówiło bliny. Były więc w użyciu słowa rosyjskie, ale sporadyczne i rzadko powtarzane. Mój ojciec nie darzył Rosjan zbyt wielką sympatią, był wobec nich nieufny, bo to, przez co tam przeszedł i co tam przeżył on i jego rodzina, po prostu ukształtowało niekoniecznie pozytywny ich obraz. Nawet kiedy uczyłam się w szkole średniej języka rosyjskiego ojciec nie chciał mi nigdy pomagać, a to przecież był język jego dzieciństwa, który tak dobrze znał. Nigdy mnie nie mobilizował do nauki tego języka. „Rosyjski? Wszystko tylko nie to. To ci niepotrzebne" jak mawiał. I tak rosyjskiego dobrze nigdy się nie nauczyłam, a szkoda. Natomiast wszyscy moi krewni opowiadali bardzo pozytywnie o indywidualnych mieszkańcach Syberii, o wielu życzliwych Rosjankach, które pomogły babci przeżyć zawieruchę wojenną tamtych czasów.

M.P.: Czy Pani dziadek miał taki sam stosunek wobec Rosji?

A.D.: Generalnie tak, ale zapamiętałam również jego zamiłowanie do literatury, także rosyjskiej. Gdy był już starszym człowiekiem, ponadosiemdziesięcioletnim i nie mógł już pracować fizycznie, wtedy częściej zajmował się mną. Chodził ze mną na spacery. Pamiętam, jak prowadził mnie za rękę, recytował 
wiersze Puszkina, Mickiewicza, Słowackiego, po polsku i po rosyjsku. To jest ciągle dla mnie niesamowite, cudowne wspomnienie mego dzieciństwa. Ja czasem teraz myślę, że wybrałam polonistykę jako kierunek moich studiów tylko dlatego, że to właśnie dziadek zaszczepił u mnie te zainteresowania i szacunek dla literatury. Nieprawdopodobna była jego pamięć i znajomość literatury, zarówno polskiej jak i rosyjskiej. I te liczne fragmenty wierszy recytowane z pamięci.

M.P.: Jak Pani ojciec zapamiętał Stany Zjednoczone?

A.D.: Mój ojciec zawsze bardzo pozytywnie i z sympatią opowiadał o Stanach Zjednoczonych. Mówił, że pobyt w Stanach był innym doświadczeniem niż pobyt $\mathrm{w}$ Japonii. W wieku 12 lat po raz pierwszy w życiu został sam, rodzice ciągle byli na Syberii, siostry w Pensylwanii, a on razem z mała grupą chłopców w stanie Connecticut. Zadziwiające, jak samotne dzieci zostawione w świecie dorosłych szybko dojrzewają. Pamiętam też, jak ojciec mi opowiadał, że nawet chciał zostać w Stanach, ale starsza ciotka - z racji wieku opiekunka rodzeństwa - powiedziała, że „nawet nie ma o czym mówić. Rodzice wysłali nas do Polski, a zatem musimy wracać do Polski, do rodziny".

$\mathrm{Na}$ początku lat 80. mój 75-letni wtedy ojciec odwiedził nas w Stanach, w Princeton, w New Jersey. Był u nas dwa miesiące. Często wspominał swoje dzieciństwo, swój pierwszy pobyt w Stanach. I to właśnie wtedy dużo opowiadał o Ameryce jego dzieciństwa. Był też taki ciekawy ówczesnej Ameryki. Czasem zastanawiał się, jak wyglądałoby jego życie, gdyby w niej został. Bardzo się cieszył bawiąc się z jego pierwszym wnukiem urodzonym w Stanach.

M.P.: Czy Pani krewni utrzymywali kontakt $z$ innymi dziećmi ewakuowanymi z Dalekiego Wschodu?

A.D.: Nie wiem. Pamiętam, że ojciec czasem mówił o innych dzieciach syberyjskich, o swoich kolegach ze szkoły ogrodniczej (zachowało się też kilka szkolnych zdjęć). Pamiętam też nazwisko pani Wróblewskiej. To jedyne nazwisko, które zapamiętałam. Ponieważ mój ojciec nigdy nie trafił do Wejherowa, tak jak większość dzieci syberyjskich, które wróciły do Polski, prawdopodobnie dlatego jego kontakt z grupą syberyjską był raczej sporadyczny. Jego siostry zaczęły naukę w seminarium nauczycielskim dopiero po krótkim pobycie w Poznaniu. Ojciec nigdy nie był w Wejherowie, więc prawdopodobnie dlatego intensywnych kontaktów z resztą dzieci syberyjskich nie było. Moja rodzina też mieszkała trochę dalej od głównych zgrupowań owych „sybiraków”, takich jak Warszawa czy okolice Poznania. Dopiero po śmierci najstarszej ciotki dowiedziałam się o listach pisanych przez nią do Józefa Jakóbkiewicza, głównego opiekuna i wychowawcy wszystkich dzieci syberyjskich, a także znalazłam jego listy pisane do ciotki Czesławy Łucji. Bardzo serdecznie opisywał radość odnalezienia się po kataklizmie II wojny światowej, o swoim małżeństwie z jedną ze swoich wychowanek, o swoich dzieciach, o tym, że wojna zastała go w Senegalu, o swojej 
pracy w szpitalu w Grenoble, powojennym powrocie do Polski i pracy w szpitalu w Cieplicach Śląskich ${ }^{25}$.

M.P.: Pani Anno, podsumowując można powiedzieć, że w pewnym sensie historia Pani rodziny zatoczyła koło. Pani ojciec chciał zostać w USA, ale nie mógł, podporządkował się woli starszej siostry. Po latach to Pani zamieszkała w tym państwie, które już od wielu lat jest dla Pani drugą ojczyzną. Przyglądając się burzliwym i niezwykłym losom rodziny Kuleszów przychodzi mi na myśl refleksja że może jej członkowie przekazują sobie z pokolenia na pokolenie jakiś ,gen emigracyjny" - swego rodzaju wewnętrzny impuls, skłaniający do poszukiwania właściwego dla siebie miejsca.

A.D.: Być może ma Pan rację, ale współczesny świat tak się zmienił, a odległości - dzięki technice tak się „,zmniejszyły”, że żyć i czuć się u siebie można praktycznie wszędzie. Najważniejsze, żeby być dobrym i uczciwym człowiekiem, rzetelnie pracować, szanować innych ludzi, pielęgnować swoją tradycję. Moje pokolenie jest chyba pierwszym powojennym pokoleniem, które nie doświadczyło tragedii wojny i rewolucji. Porównując życie moich przodków i moje, myślę, że teraz jest chyba najlepiej. Możemy marzyć, podróżować, uczyć się i budować wolną przyszłość. Mam nadzieję, że nasze dzieci też będą mogły żyć w wolnym kraju, w wolnym i bezpiecznym świecie. Wolność i pokój to takie niesłychanie ważne i istotne wartości, ale bardzo delikatne, bo tak łatwo można je stracić, a odbudować będzie bardzo trudno i ciężkim kosztem.

M.P.: Dziękuję za rozmowę

A.D.: Dziękuję.

25 Wojna zastała Jakóbkiewicza we francuskim Senegalu, gdzie jako specjalista od chorób tropikalnych, zajmował się kształceniem lekarzy. Następnie przeniósł się do Francji, gdzie przebywał do 1946 r. pracując dla Czerwonego Krzyża. Po powrocie do Polski został skierowany do pracy w uzdrowisku w Cieplicach Śląskich. Zmarł w 1953 r. W. Theiss, op. cit., s. 49-50. 